\title{
BIBLIOGRÁFIA
}

\section{A magyar nyomda-, könyv-, sajtó- és könyvtártörténeti szakirodalom 2019*-ben}

\section{Rövidítések}

\author{
GeodKart \\ HadtörtMúzÉrt \\ ItK \\ KEK \\ $\mathrm{KF}$ \\ $\mathrm{KN}$ \\ MG \\ MKsz \\ MNyelv \\ MVízjel \\ MüvtörtÉrt \\ Átfedések...
}

$=$ Geodézia és Kartográfia

A Hadtörténeti Múzeum Értesítője

$=$ Irodalomtörténeti Közlemények

= Közép-Európai Közlemények

= Könyvtári Figyelő

= Könyv és Nevelés

= Magyar Grafika

= Magyar Könyvszemle

= Magyar Nyelv

= Magyar Vízjel

= Mủvészettörténeti Értesítő

= Átfedések. Szövegalkotás a 16-18. századi irodalomban / szerk. Kiss FARKAS Gábor és MACZÁk Ibolya. Bp.: MTAPPKE Barokk Irod. és Lelkiség Kutcsop. - MTA-ELTE HECE, 2019. 172 p. ill. (Pázmány irodalmi mühely. Lelkiségtörténeti tanulmányok; 22.)

„A hazának hủ öre és oszlopa”.. = „A hazának hü őre és oszlopa”. Szepesy Ignác pécsi püspök emlékezete. Tudomány és kutatás a Klimo Könyvtárban. A 2018. október 4-én rendezett tudományos konferencia tanulmányai / szerk. MÉreg Martin, MolnáR Dávid, SCHMELCZER-PohánKa Éva. Pécs: PTE Egyetemi Kvt. és Tudásközp. - Pécsi Egyházmegye, 2019. 237 p. ill. (A Pécsi Egyetemi Könyvtár kiadványai; 17.)

Írások a Pray-kódexről...
= Írások a Pray-kódexröl / szerk. BARTóK Zsófia Ágnes, HorváTH Balázs. Bp.: Argumentum K.- ELTE BTK Vallástud. Közp. Liturgiatört. Kutcsop., 2019. 178 p. ill. (Mühelytanulmányok / ELTE BTK Vallástudományi Központ Liturgiatörténeti Kutatócsoport; 5.)

\footnotetext{
* 2017-es és 2018-as impresszummal megjelent publikációk pótlásával.
} 
Keresztény megújulási mozgalmak...= Keresztény megújulási mozgalmak, 1500-1800. Keresztény megújulási mozgalmak, 1500-1800 c. konferencia. Budapest, 2018. április 5. / szerk. BoRos István. Bp.: Szt. István Társ., 2019. 138 p. ill.

„Közöttünk a’ mester”

$=$ „Közöttünk a’ mester”. Tanítványi köszöntökötet a 60 éves Debreczeni Attila tiszteletére / szerk. BóDI Katalin, BoDroGi Ferenc Máté. Debrecen: Debreceni Egy. K., 2019. 252 p. ill.

Media and literature...

$=$ Media and literature in multilingual Hungary, 1770-1820/ ed. by Ágnes DóBÉK, Gábor MÉszáRos and Gábor VADERnA. Bp.: Reciti, 2019. 285 p. (Reciti conference books; 3.)

Nőszerzők a 19. században... = Nőszerzők a 19. században. Lehetőségek és korlátok / szerk. TÖRÖK Zsuzsa. Bp.: Reciti, 2019. 375 p. (Reciti konferenciakötetek; 4.)

Reformácia v strednej Európe... = Reformácia v strednej Európe / eds. Annamária KónYové, Peter KónYa. Prešov: Vydavatel'stvo Prešovskej univerzity, 2018. 1.610 p. ill.; 2. 801 p. ill.

Személyek, intézmények... = Személyek, intézmények szerepe a hívek lelkiségének alakításában a 17-18. században / szerk. Szelestei N. László. Bp.: MTA-PPKE Barokk Irod. és Lelkiség Kutcsop., 2019. 241 p. ill. (Pázmány irodalmi műhely. Lelkiségtörténeti tanulmányok; 24.)

Teleki József...

= Teleki József. Tanulmányok az Akadémiai Könyvtár alapítójáról és a Magyar Tudományos Akadémia első elnökéről / szerk. Molnár Andrea. Bp.: MTA KIK, 2019. 228 p. ill. (A Magyar Tudományos Akadémia Könyvtárának közleményei. Új sorozat; 40=115.) https://doi.org/10.36820/MTAKIK.KOZL.2019.TELEKI

Térképtörténeti Közlemények... = Térképtörténeti közlemények. 3. Az Országos Széchényi Könyvtár Térképtárának évkönyve 2018./ főszerk. Pászti László. Bp.: OSZK, 2019. 132 p. ill.

Újfalvi Imre pere és műveltsége... = Újfalvi Imre pere és műveltsége. Tanulmányok és szövegközlések / szerk. OLÁH Róbert. Debrecen: Tiszántúli Református Egyházker. Gyüjt., 2019. 199 p. ill.

\section{Általános és összefoglaló munkák, elvi kérdések}

BAJÁKI Rita: Katolikus főpapok irodalmi tevékenysége a kora újkori Magyarországon (1550-1670) = Személyek, intézmények... 9-25.

BÁNDI András: A Romániai Evangélikus Egyház Gyüjtőlevéltárának a reformációhoz kapcsolódó nyomtatványai = MKsz (135.) 2019. 2. 219-229. https://doi.org/10.17167/mksz.2019.2.219-229 A tanulmány a nyomtatványok könyv- és olvasástörténeti szempontú vizsgálata

BÁNDi András-Palotás György: Egy medgyesi Cyprianus-kötet és Verancsics Antal epitáfiumai Adrianus Wolphardus halálára (1544) = Lymbus 2019. 9-18.

Verancsics Antal epitáfiumainak szövegközlésével

BÁNRÉVI Mónika: Oktatás és müvelődés Erdődy Gábor egri püspök időszakában, 1715-1744 = „A tudomány ekként rajzolja világát”. Irodalom, nevelés és történelem metszetei I. Tanulmánykötet. Az Eszterházy Károly Egyetem Doktorandusz Önkormányzata, az Eötvös Loránd Tudo- 
mányegyetem Doktorandusz Önkormányzata és a Doktoranduszok Országos Szövetsége Irodalomtudományi Osztály I. közös konferenciájának tanulmánykötete / szerk. FoDoR József Péter, Mizera Tamás, SzABó P. Katalin. Eger: EKE Doktorandusz Önkormányzat; Bp.: ELTE EDÖK- DOSZ Irodalomtudományi Oszt., 2019. 10-34.

Könyvtörténeti adatokkal: Erdődy Gábor egri püspök és Kiss János olvasókanonok könyves müveltségéröl

BÁRÁNY Zsófia: Catholic and Protestant Union-Plans in the Kingdom of Hungary between 1817 and 1841. The Golden Age of „Public Opinion” and the Memory of the Reformation in Veszprém County $=$ Media and literature... 253-268.

A vallási unió kérdéséről a 19. század eleji Veszprém megyében a sajtó és egyéb kiadványok tükrében

Berecz Ágnes: Ráday Gedeon a tudás hasznáról = Lelkészek, nemesek, polgárok. Tanulmányok a Ráday Gyüjteményből / szerk. Berecz Ágnes. Bp.: Ráday Gyüjtemény, 2019. 33-47. https:// doi.org/10.51183/RGYT_18

Ráday Gedeon levelének közlésével, könyvtárára, olvasmánymüveltségére vonatkozó adatok$\mathrm{kal}^{1}$

BÉRES Norbert: Kártigámnak emlékezetes történetei. Közelítések a 18. század végének népszerü prózairodalmához = ItK (123.) 2019. 5. 585-603.

BoDA Miklós: „A Föld indulása lévén 1739. Die 4. Februarius”. Bejegyzések és más megkülönböztető jegyek a pécsi püspöki könyvtár egyes köteteiben = „A hazának hü őre és oszlopa”... 131-144. ill.

Bujtás László Zsigmond: Sárkány Pál ajándékai 1777-ből = Egyháztört. Szle (20.) 2019. 2. 106 111.

CsATA Adél: A historia litteraria Benkő József koncepciójában = Certamen VI. Előadások a Magyar Tudomány Napján az Erdélyi Múzeum-Egyesület I. Szakosztályában / szerk. EGYED Emese, PAKó László, Sófalvi Emese. Kolozsvár: Erdélyi Múzeum-Egyes., 2019. 35-51. https://doi. org/10.51384/cert-06.04 Az erdélyi könyvtörténetre vonatkozó adatokkal

CZENTHE Miklós: A Lőcsei evangélikus levéltár története = Reformácia v strednej Európe... 2. köt. 222-257.

Könyv-, könyvtártörténeti vonatkozású részekkel

DóвÉK Ágnes: Szily János püspök irodalompártoló tevékenysége = Személyek, intézmények... $47-54$.

Dомокоs Mariann: Gaal György mesegyüjteménye és a populáris olvasmányok = Ethnographia (130.) 2019. 3. 418-444.

ECSEDY Judit, V.: A Trattnerek Magyarországon - egy évforduló alkalmából = MG (63.) 2019. 4. 62-67. ill.

ECSEDY Judit, V.: A Trattnerek Magyarországon = MKsz (135.) 2019. 2. 173-189. ill. https://doi. org/10.17167/mksz.2019.2.173-189

FARKAS Gábor Farkas: Elpusztult és lappangó brünni Thuróczy-példányok = MKsz (135.) 2019. 3. 346-365. https://doi.org/10.17167/mksz.2019.3.346-365

FEJős Sándor: Magyarkanizsa müvelődéstörténete, 1867-1918. Szeged: Szegedi Egy K.- JGYF K., 2019. 218 p. ill.

Olvasástörténetre, sajtótörténetre vonatkozó részekkel, fejezettel: 21-28. 124-125. 137-162.

1 A tanulmány téves impresszummal egyszer már megjelent a 2018-as publikációkat összegző könyvtörténeti bibliográfiában. 
FraUHAMMER Krisztina: Imák és olvasatok: imakönyvek a 19-20. századi Magyarországon / szerk. KereKes Ibolya. Szeged: SZTE BTK Néprajzi és Kulturális Antropológiai Tanszék-MTASZTE Vallási Kultúrakut. Csop., 2019. 249 p. ill. (A vallási kultúrakutatás könyvei; 42.)

GoLuB Xénia: Vitkovics János, a tabáni székesegyház papja és a szerb műveltség Budán a 19. század első felében = Szerb székesegyház a Tabánban. Az eltűnt Rácváros emlékezete. 2018. november 9 - 2019. március 31. Kiállitási katalógus / kurátor Csáki Tamás; szerk. Csáki Tamás, Golub Xénia. Bp.: BTM; Novi Sad: Matica Srpska Képtár; Szentendre: Szerb Egyh. Múz., 2019. 273-304. ill.

Könyvtörténeti adatokkal

GöMöRI György: Köleséri Sámuel Royal Society-tagságának előzményei és hitelesítése = MKsz (135.) 2019. 4. 489-497. ill. https://doi.org/10.17167/mksz.2019.4.487-497

Könyvtörténeti adatokkal

Sir Hans Sloane latin nyelvü levelének szövegközlésével

HegYi Ádám: Mária Terézia alakja a református kegyességben a Körös-Maros Közi Szent Társaságban = Második Mária. Mária Terézia a régi magyarországi kegyességben / szerk. MACZÁK Ibolya. Bp.: MTA-PPKE Barokk Irod. és Lelkiség Kutcsop., 2019. 65-76.

Könyv- és olvasmánytörténeti adalékkal

HoRváTH Sándor: A népmissziók és hatásuk. Mulih György horvát jezsuita példája nyomán = Személyek, intézmények... 55-66.

Könyvtörténeti adatokkal

HUBERT Gabriella, H.: Éneklés a magyarországi reformáció első két századában = Ige-idők. A reformáció 500 éve. Magyar Nemzeti Múzeum, 2017. április 26 - november 5. / szerk. Kiss Erika, ZÁszKaliczKy Márton, ZÁszKaliczKy Zsuzsanna; térk. Nagy Béla. Bp.: MNM, 2019-. Tanulmányok. 174-183. ill.

Énekeskönyv kiadástörténeti adatokkal

KasZA Péter: „Parturiunt montes, nascetur ridiculus mus”. Kritikai észrevételek Botlik Richárd Előszó egy elveszettnek hitt szövegváltozat magyar nyelvű kiadásához = MKsz (135.) 2019. 1. 95-116. https://doi.org/10.17167/mksz.2019.1.95-116

KесSкEмÉTI Gábor: Medgyesi Pál prédikációelméleti művének forrásai = ItK (123.) 2019. 2. 158 169.

KNAPP Éva: Palingenius Zodiacus vitaejének magyarországi fordításai $=$ A reformáció és a katolikus megújulás latin nyelvü irodalma / szerk. BÉKÉs Enikő et al. Bp.: MTA BTK ITI, 2019. 173-183.

Manzolli: Zodiacus vitae c. mủvének magyar nyelvü kéziratairól és a mủ részletének Lőcsén megjelent, német nyelvű kiadásáról

KóNYA Annamária: Különleges Bibliák az Eperjesi Evangélikus Kollégiumban = Egyháztört. Szle (19.) 2018. 2. 130-133.

Kutı Klára: Az utolsó pillanatban. Bornemisza Anna szakácskönyve és egy korszak vége $=$ Soproni Szle (73.) 2019. 2. 168-176. ill.

2018. október 2-án a Magyar Nemzeti Levéltár Győr-Moson-Sopron Megye Soproni Levéltára gasztronómiatörténeti konferenciáján elhangzott előadás jegyzetekkel kiegészített, átdolgozott változata

LengYel András: Tömörkény-tanulmányok. Szeged: Tiszatáj Alapítvány, 2019. 347 p. ill. (Tiszatáj könyvek)

Korábban megjelent tanulmányok az életrajzi és irodalomtörténeti dolgozatok mellett a kiadástörténet, könyvtártörténet, sajtótörténet területéröl

LENGYel Réka: The first student's guides to natural sciences in the eigtheenth-century Hungary. Physicotheology in translation = Kniha (Martin,Slovenská Národná Kniznica) 2019. 103-110. 
LENGYEL Tünde: A kora újkori női müveltség problémái. Elvárások, határok és lehetőségek = A női kommunikáció kultúrtörténete. Tanulmányok / szerk. SIPos Balázs, Krász Lilla. Bp.: Napvilág, 2019. 21-33.

A 16. századi női alfabetizáció kérdéséhez

A szerző tartalmilag csaknem megegyező tanulmánya megjelent: Századok (153.) 2019. 2. $235-250$.

LENGYEL Tünde: Esettanulmány a kora újkori női műveltség kérdéséhez. Elvárások, lehetőségek, határok. Századok (153.) 2019. 2. 235-250.

A 16. századi női alfabetizáció kérdéséhez

A szerző tartalmilag csaknem megegyező tanulmánya megjelent: A női kommunikáció kultúrtörténete. Tanulmányok / szerk. SIPos Balázs, KRÁsz Lilla. Bp.: Napvilág, 2019. 21-33.

Magyarkanizsa monográfiája, 1848-1945. Kanizsa monográfiája 2. / föszerk. Fesős Sándor. Magyarkanizsa: József A. Kvt., 2018. 516 p. ill.

Sajtótörténetre vonatkozó fejezet: DöBöR András-PEтő Bálint: A magyarkanizsai sajtó kezdetei (1909-1918). 352-398.

Mıкó Árpád: Reneszánsz művészet Mátyás király udvarában = Mátyás király emlékkönyv / szerk. BóDvAi András. Bp.: Magyarság Háza, 2019. 183-203. ill.

MısÁK Marianna: A Lelki Ábécé egyháztörténeti megközelítésből = Egyháztört. Szle (20.) 2019. 2. 26-38. 103.

Miskolczy Ambrus: Széchényi Ferenc a szabadkőművesség erénykultuszától a katolikus megújulásig. Bp.: Universitas, 2019. 152 p.

A könyvtáralapító: $38-44$.

MoLNÁr Dávid: Szenci Molnár Albert. Példaszócikk egy készülő enciklopédiából = MKsz (135.) 2019. 1. 50-90. https://doi.org/10.17167/mksz.2019.1.50-90

MoNoK István: Szerzetesi humanizmus, kegyességi irodalom a XVI. század elején = Keresztény megújulási mozgalmak...43-51.

Általános európai áttekintés magyar vonatkozással

MonoK István: Michael Denis’ Vorwort zum Katalog der Ödenburger Bibliothek des Ferenc Szechenyi $=$ Kulturelle Zirkulation im Habsburgerreich. Der Kommunikationsraum Wien / Hg. Wynfried Kriegleder, Andrea Seidler, Jozef TanCER. Wien: Praesens Verlag, 2019. 98-102.

MoNOK István: A reformáció és a könyvek. Kiadói és szellemi központok $=$ Laborator assiduus. A 70 éves Zombori István köszöntése / szerk. SomorjaI Ádám, SomorjaI Gabi. Bp.: MTA BTK TTI-MNL Orsz. Lvt., 2019. 179-185.

A Magyar Királyságra (is) vonatkozó könyvtörténeti adatokkal

NAGY Andor: A brassói Honterus Gimnázium kora újkori disputációi = Acta Universitatis de Carolo Eszterházy Nominatae. Sectio Historiae. 46. 2019. 261-271.

NyAKas Miklós: Zwingli a Hajdúságban. A Hajdúböszörmény-Kálvin téri gyülekezeti könyvtár egyik nagy értékủ darabjáról. Zwingli: An die durchtlüchtigen Fürsten tütscher Nation... Zürich, 1530 = Reformácia v strednej Európe... 1. köt. 325-340.

PAJORIN Klára: Asztrológia, mágia és Apuleius-kultusz Mátyás király mủveltségében = Mátyás király emlékkönyv / szerk. BóDvaI András. Bp.: Magyarság Háza, 2019. 161-171. ill.

PESTI Brigitta: Nők szerepe és jelentősége a 17. századi könyvkiadás mecenatúrájában $=$ A női kommunikáció kultúrtörténete. Tanulmányok / szerk. SiPos Balázs, KRÁsz Lilla. Bp.: Napvilág, 2019. 138-155.

PESTI Brigitta: Női olvasók, női mecénások a 17. század kegyességi irodalmában = A nők jelenléte és szerepe a magyar protestáns szellemiségben / szerk. Dienes Dénes, KegYes Erika, Veres Ildikó. Sárospatak: Hernád, 2019. 99-119. 
SzABó András: Újfalvi Imre és a wittenbergi magyar coetus = Újfalvi Imre pere és müveltsége... $105-110$.

Újfalvi Imre wittenbergi peregrinációja, a magyar coetus életében vitt vezető szerepe, album amicoruma

SzeleStei NaGy László: Nagy Ignác püspök, a székesfehérvári egyházmegye lelkületének szervezője = Személyek, intézmények... 165-172.

SzIGETI Jenő: Egy imádkozni tanító kolozsvári esperes a 18. század elejéről = Személyek, intézmények... 173-178.

Szathmári Pap János: Kegyes ajakak áldozó tulkai c. müvéről

SzILÁGYI Zita Mária: Jósika Júlia sz. báró Podmaniczky Júlia írótevékenysége a neoabszolutizmus éveiben $=$ A nők jelenléte és szerepe a magyar protestáns szellemiségben / szerk. DiENEs Dénes, KegYes Erika, Veres Ildikó. Sárospatak: Hernád, 2019. 183-194.

Kiadás-, olvasmány- és sajtótörténeti adalékokkal

SzÖRÉNYI László: Johannes Campanus cseh neolatin költő és a magyar történelem = Antikvitás \& reneszánsz (2.) 2019. 3. 209-230. https://doi.org/10.14232/antikren.2019.3.209-230

A tanulmány szerzője Campanus szövegét, mint tartalmi hungarikát mutatja be

Teleki József. Tanulmányok az Akadémiai Könyvtár alapítójáról és a Magyar Tudományos Akadémia első elnökéről / szerk. MolnÁR Andrea. Bp.: MTA KIK, 2019. 228 p. ill. (A Magyar Tudományos Akadémia Könyvtárának közleményei. Új sorozat; 40=115.) https://doi.org/10.36820/ MTAKIK.KOZL.2019.TELEKI

Tanulmányok az Akadémiai Könyvtár alapítójáról és a Magyar Tudományos Akadémia első elnökéröl

Függelék: A gróf Teleki család könyvgyüjtő és könyvtáralapító tagjainak családfája: 218-219.

То́тн Ferenc: Az erényes politikus példaképe. Bercsényi László gróf francia életrajza egy 18. századi lotharingiai politikai értekezésben $=$ MKsz (135.) 2019. 2 .234-240. https://doi. org/10.17167/mksz.2019.2.234-240

То́тн Zsombor: Hosszú reformáció Magyarországon és Erdélyben 1.Konfesszionalizációk és irodalmi kultúrák a kora újkorban, 1500-1800. Módszertani megjegyzések egy folyamatban lévő kutatáshoz $=\mathrm{ItK}$ (123.) 2019. 6. 719-739.

Könyvtörténeti adatokkal

VADERNA Gábor: A Sebestyén család Bibliája = Doromb 2019. 7. 229-239.

VAss Csongor: Baranyi Pál Viaticum spirituale (1695) kötetének Dedicatiója gróf Gyulaffy Lászlóhoz = Személyek, intézmények... 195-211.

VERóK Attila: Gondolatok az erdélyi szász (könyves) kultúráról = „Az élet éppen elég hosszú”. BG 60. Írások Balázs Géza 60. születésnapjára / szerk. Blankó Miklós, PöLCz Ádám. Bp.: Inter Nonprofit Kft., 2019. 163-166.

VeróK Attila: Buchkultur im Spannungsfeld von zwei Reformationen bei den Siebenbürger Sachsen (16-18. Jahrhundert) = Reformácia v strednej Európe... 2. köt. 673-695.

VesZPRÉMY László: Történetírás és történetírók az Árpád-kori Magyarországon. XI-XIII. század közepe $=$ History writing and historians in Hungary during the reign of the Arpad Dynasty. Eleventh - mid thirteenth century. Bp.: Line Design, 2019. 464 p. (Rerum fides; 2.) Könyv-, könyvtár- és olvasmánytörténeti részekkel

Zsupán Edina: A Corvina könyvtár budai mühelye. Az Országos Széchényi Könyvtár kiállításának eredményei = Századok (153.) 2019. 5. 997-1036.

ZvARA Edina: Ein ungarischer Literaturorganisator in Wien. Demeter Görög (1760-1833) = Kulturelle Zirkulation im Habsburgerreich. Der Kommunikationsraum Wien / Hg. Wynfried KRIEGLEDER, Andrea SeIDler, Jozef TANCER. Wien: Praesens Verlag, 2019. 114-143.

Könyvtártörténeti, sajtótörténeti adatokkal 


\section{Bibliográfiák, repertóriumok, katalógusok}

BíRó Gyöngyi: A Ráday Gyüjtemény Könyvtárának készülő antikvakatalógusa = Lelkészek, nemesek, polgárok. Tanulmányok a Ráday Gyüjteményből / szerk. Berecz Ágnes. Bp.: Ráday Gyüjtemény, 2019.70-78. ${ }^{2}$ A tanulmánykötet DOI azonosítója (a tanulmánynak külön nincs): https:// doi.org/10.51183/RGYT_18

BoRVÖLGYI Györgyi: A magyar nyomda-, könyv-, sajtó- és könyvtártörténeti szakirodalom 2018ban = MKsz (135.) 2019. 4. 505-531. https://doi.org/10.17167/mksz.2019.4.505-531

GoRDÁn Edina: A dési ferences rendház könyvtárának régi állománya $=$ Altbücherverstand der Bibliothek des Franziskanerklosters in Deesch = Fondul de carte veche al Mănăstiri Franciscani din Dej. Bp.: MTA KIK, 2019. LXXXIII, 748 p. ill. (A Kárpát-medence magyar könyvtárainak régi könyvei; 13.)

HÁsz-FeHÉr Katalin: Arany János nagyszalontai könyvtárának és széljegyzeteinek katalógusa. Bp.: Universitas- MTA BTK ITI, 2019. 1065 p.

HegYi Ádám: Hungarica in der Dissertationssammlung des Nürnberger Naturforschers und Arztes Christoph Jacob Trew (1695-1769). Katalog. 1582-1765. Bp.: MTA KIK, 2019. 147, 294 p. (Bavarica et Hungarica; 3.)

HuRSÁN Szabolcs: Batthyány Lajos nádor (1696-1765) katalógusa különös tekintettel a magyar vonatkozású és antik anyagra, valamint a Theologici szak anyagára. Az Akadémiai Könyvtár Batthyány-könyvállománya és Batthyány Lajos katalógusa = MKsz (135.) 2019. 2. 138-172. https://doi.org/10.17167/mksz.2019.2.138-172

NAGYI Enikő Orsolya: Zsidó sajtókiadványok Erdélyben = Me.dok (14.) 2019. 4. 7-18. ill.

RÁcz Emese: A nagyenyedi Bethlen Kollégium könyvtárának XVIII. századi gyüjteményei. Bp.: MTA KIK, 2019-.

1. A Hungarika téka. 2019. 125 p. ill. (A Kárpát-medence koraújkori könyvtárai; 10.)

SzÜGYI-SzŰCS Judit-Veres Anna Mária: A gyulafehérvári Római Katolikus Papnevelő Intézet „Seminarium Incarnatae Sapientiae” könyvtárának régi állománya = Altbücherbestand der Bibliothek des Priesterseminar „Seminarium Incarnatae Sapientiae” in Alba Iulia = Fondul de carte veche al seminarului Teologic Romano Catolic „Seminarium Incarnatae Sapientiae” din Alba Iulia. Bp: MTA KIK, 2019-.

1. Az 1601 elötti nyomtatványok és a Régi Magyar Könyvtár = Drucke des XVI. Jahrhunderts und Alte Ungarische Bibliothek $($ RMK) = Catalogul tipariturilor anterioare anului 1601 si Biblioteca Maghiara Veche (RMK). 2019. 142 p. (A Kárpát-medence magyar könyvtárainak régi könyvei; 12.)

TAKó Edit: Régi evangélikus könyvek (1518-1850) Somogyi Károly kanonok könyvtárában = A magyarországi evangélikusok az ország müvelődésében és kultúrájában. 18-20. század / szerk. Zombori István. Bp.: METEM- Historia Ecclesiastica Hungarica Alapítvány, 2019. 185-204.

A könyvek katalógusa a Függelékben olvasható: 191-204.

2 A tanulmány téves impresszummal egyszer már megjelent a 2018-as publikációkat összegző könyvtörténeti bibliográfiában. 


\section{Könyvtörténet/Kéziratosság, kódexek}

Antiphonale Varadinense s. XV / közread. ... CZagány Zsuzsa. Bp.: BTK ZTI, 2019. (Musicalia Danubiana; 26.). 1. köt. Proprium de tempore. 100 p. ill.; 2. köt. Proprium de sanctis et commune sanctorum. 54 p. ill.; 3. köt. Tanulmányok. 339 p. ill.

Tart.: A Váradi Antifonále bemutatása; A váradi székesegyház és könyvei a késő középkorban és a kora újkorban; A források; A Váradi Antifonále liturgikus énekanyaga. A tételkészlet elemző bemutatása

Az eredeti kódex fotómásolatával

A 3. kötetben Czagány Zsuzsa tanulmányai

BAJÁKi Rita: Csáky Éva Franciska írásai. Bp.: MTA-PPKE Barokk Irod. és Lelkiség Kutcsop., 2019.276 p. (Pázmány irodalmi mühely. Lelkiségtörténeti források; 7.) https://doi.org/10.36817/ KM.2019.1.1

Forráskiadás.

Bajáki Rita bevezető tanulmánya: 9-24.

BAJNOK Dániel: Aischinés a Bibliotheca Corvinianában = Hunyadi Mátyás és kora / szerk. BÁRÁNY Attila et al. Debrecen: MTA-DE Lendület „Mo. a középkori Európában” Kutcsop., 2019. 4156. ill.

A BSB Clm 310. jelzetű Corvina kódexről

EkLER Péter: Georgius Trapezuntius, Johannes Regiomontanus and the Defensio Theonis = Byzanz und das Abendland VI. Studia Byzantino-Occidentalia / hrsg. von Erika JuHÁsz. Bp.: Eötvös-József-Collegium, 2019. 211-218.

EKLER Péter: Johannes Regiomontanus: Tabula primi mobilis. A Source Publication of the Dedication to King Matthias Based on Four Manuscripts = Studia bibliographica Posoniensia. 2019. $11-20$.

Négy kódex dedikációszövegének összehasonlítása: Budapest, Országos Széchényi Könyvtár, Cod. Lat. 412; Besançon, Bibliothèque municipale, Ms 481; Cracow, Biblioteka Jagiellońska, Cod. 594; Nürnberg, Stadtbibliothek, Cent. V, 17.

ERDős Zoltán Mátyás-RAuSCH Petra: Egy oktatástörténeti kuriózum Jenei G. István iskolai jegyzetei $=$ Per aspera ad astra (5.) 2018. 1. 60-75. ill. https://doi.org/10.15170/PAAA.2018.05.01.04 Eletronikus dokumentum: https://per-aspera.pte.hu/archivum/2018-1-szam-8.html

FARKAS Flóra: Céduláktól a kódexig. A compilatio folyamata a Tractatulus de chorea St. Paul in Lavanttal cod. 236/4 jelzetủ kéziratában = Átfedések... 7-19. ill.

A budai keltezésủ Tractatulus de chorea cod. 236/4 jelzetü kéziratáról

FARKAS Gábor Farkas: Codices, incunabula and the Theuerdank = Kniha (Martin,Slovenská Národná Kniznica) 2019. 7-19.

Az OSZK Kézirattárának MNy 73. és MNy 74. jelzetű nyelvemlékkódexeiről

FöLDVÁRY Miklós István: Gyászszertartások a régi magyar liturgiában = Írások a Pray-kódexröl... 65-96.

GILÁNYI Gabriella: 15. századi erdélyi antifonále-töredékek és ferences hordozókönyveik = A Csíki Székely Múzeum évkve 2019. 95-110. ill.

GILÁNYI Gabriella: Mozaikok Erdély ismeretlen gregorián hagyományából. Egy Anjou-kori antifonále töredékei Güssingben. Egy Anjou-kori antifonále töredékei Erdélyben = Mosaics of the plainchant tradition of Transylvania. Interpreting the 14th-century antiphoner fragments at Güssing. Bp.: BTK ZTI, 2019. 217 p. ill. (Resonemus pariter; 1.)

Tart.: Bevezetés-A németújvári gyüjtemény; 14. századi antifonále-töredékek-Kodikológiai áttekintés; Libri liturgici ex Transylvania - A gregoriánkutatás eddigi eredményei; A zenei vizs- 
gálatok összehasonlító forrásanyaga; Zenei paleográfiai analízis; Liturgiai elemzés; A dallamok összehasonlító vizsgálata; Összegzés; Függelék; Bibliográfia: 9-96.

A kötet tartalma angol nyelven: 97-176.

GöMÖRI György: Magyar közmondások és tréfás bejegyzések XVI-XVIII. századi albumokban = Doromb 2019. 7. 63-71.

Gradvohl Edina: Mátyás király gyógyszerkönyve - Bibliotheca Casanatense Ms. 459. = Hunyadi Mátyás és kora / szerk. BÁRÁNY Attila et al. Debrecen: MTA-DE Lendület „Mo. a középkori Európában” Kutcsop., 2019. 34-40. ill.

HoRváTH Balázs: A Pray-kódex kalendáriuma és szanktoráléja európai összehasonlításban = Írások a Pray-kódexröl... 47-63. ill.

Huszti László: Calvinus János élete. Forráskiadás. / bev. és sajtó alá rend. Tóтн Zsombor; a kéziratot átírta PAPP Kinga. Bp.: Reciti, 2019. 129 p. ill. (ReTextum; 10.)

Huszti László Kálvin-biográfiája (1758)

Tóth Zsombor bevezető tanulmánya: 11-47.

Írások a Pray-kódexről / szerk. BARTóK Zsófia Ágnes, HoRváth Balázs. Bp.: Argumentum K. ELTE BTK Vallástud. Közp. Liturgiatört. Kutcsop., 2019. 178 p. ill. (Műhelytanulmányok; 5.)

KÁPOLNÁsI Zsolt: Orbán Balázs adatgyűjtő jegyzetfüzete az Országos Széchényi Könyvtárban = Acta siculica 2018/2019. 209-217. ill.

Az OSZK Kézirattárának Duod. Hung. 181 jelzetű dokumentumáról

Kasza Péter: „Kézirat sosem ég el”. Caspar Ursinus Velius mohácsi csatáról írott beszámolójának és egyéb töredékeinek kézirata az OSZK-ban=MKsz (135.) 2019.1.36-49. https://doi.org/10.17167/ mksz.2019.1.36-49

KisDi Klára: Egy tizenkét darabos PAZL Varjú Elemér hagyatékából. Lambachi kódextöredékek az OSZK-ban = MKsz (135.) 2019. 3. 253-278. ill. https://doi.org/10.17167/mksz.2019.3.253-278

KóNYA Franciska: Virág Jácint kéziratos elmélkedésgyüjteménye - Vásárhelyi Gergely találkozása Pázmánnyal = MKsz (135.) 2019. 4. 482-489. https://doi.org/10.17167/mksz.2019.4.482-489

Korondi Ágnes: Hungarian Psalm Translations and Their Uses in Late Medieval Hungary = Vernacular Psalters and the Early Rise of Linguistic Identities. The Romanian case / ed. Vladimir Agrigoroaei, Ileana Sasu, Ana Dumitran. Bucureşti: Dark Publishing, 2019. 64-72. ill.

MADAs Edit: Kegyesség és anyanyelvủ írásbeliség Magyarországon a XVI. század első harmadában = Keresztény megújulási mozgalmak... 37-42.

Mıкó Gábor: A formuláskönyv és a leveleskönyv határán. Az Országos Széchényi Könyvtár Fol. Lat. 1656. számú kézirata = Acta Universitatis Szegediensis. Acta Historica. 144. 2019. 83-93.

Mıкó Gábor: Oláh Miklós formuláskönyve. Bevezető tanulmány egy készülő kiadáshoz = Történelmi Szle (61.) 2019. 4. 617-632.

MølLer, Morten Kock- Roe, Joshua: „Luther demolished the roofs, Calvin the walls, but Socinus destroyed the foundations". The ambivalence of religious tolerance in Hungary according to Mihály Virág = „A hazának hủ őre és oszlopa”... 103-116.

Molnár Dávid: „Many laughed at the thought of this illustrious young man reading books”. About Miklós Báthory's Library and His Cicero-Codex = The Hungarian historical review (8.) 2019. 3. 573-593. ill. Az OSZK Cod. Lat. 150. jelzetü kéziratáról

Ősz Sándor Előd: Szenci Molnár Albert levélgyüjteménye, a Collectio Molnariana = Hagyomány, identitás, történelem. HIT 2018. / szerk. KIss Réka, LÁNYI Gábor. Bp.: Károli Gáspár Református Egyetem- L'Harmattan Kiadó, 2019. 71-88.

PAPP Sándor: A Képes Krónika, Thuróczy János krónikája és a Tárih-i Üngürüsz kapcsolata. Volt-e „török fogságban” a Képes Krónika? = Szent Márton és Benedek nyomában. Tanulmányok 
Koszta László emlékére / szerk. Fedeles Tamás, Hunyadi Zsolt. Szeged: SZTE Középkori és Kora Újkori M. Tört. Tansz.; Debrecen: FIKP „Mo. a középkori Európában” Kutcsop., 2019. 342-357.

SARBAK Gábor: Szalkai László esztergomi érsek iskoláskönyvének facsimile kiadása = Szalkai-kódex. Szalkai László esztergomi érsek iskoláskönyve = Szalkai Codex. The textbook of László Szalkai, Archbishop of Esztergom / sajtó alá rend. és a bev. tanulmányt írta SARBAK Gábor. Hasonmás kiad. Esztergom: Esztergomi Főszékesegyházi Könyvtár- Sárospataki Római Katolikus Gyüjtemény, 2019. IX-XXVIII.

A tanulmány angol nyelven: XXXIII-LII.

Eredeti kézirat: Esztergomi Főszékesegyházi Könyvtár, MS II. 395.

SARBAK Gábor-Zsoldos Endre: Soloneus és Iohannes Bedellus Esztergomban. A Főszékesegyházi Könyvtár Ms. I. 186. jelzetü kódexe = Magyar Sion (13.) 2019. 2. 193-232. ill.

Szalkai-kódex. Szalkai László esztergomi érsek iskoláskönyve $=$ Szalkai Codex. The textbook of László Szalkai, Archbishop of Esztergom / sajtó alá rend. és a bev. tanulmányt írta SARBAK Gábor. Hasonmás kiad. Esztergom: Esztergomi Főszékesegyházi Könyvtár- Sárospataki Római Katolikus Gyüjtemény, 2019. LIII, 522 p.

Somogy Szilvia: Az esztergomi szinodális könyvről. Új források, redakciók és szövegtöbbletek nyomában. Elötanulmány egy disszertációfejezethez = MKsz (135.) 2019. 1. 1-17. https://doi. org/10.17167/mksz.2019.1.1-17

SZENTGYÖRGYI Rudolf: A Halotti beszéd és a halotti könyörgés = Írások a Pray-kódexröl... 97-110.

SzoLIVA Gábriel: Hymnuale ecclesiae Zagrabiensis. Hagyománytisztelet és egyéni alakítás a zágrábi székesegyház 15. század eleji himnáriumában. Traditionalism and Innovation in the Early 15th-Century Hymnal of Zagreb Cathedral. Tradicionalni i novi elementi u himnariju Zagrebačke katedrale s početka 15. stoljeća. Bp.: BTK ZTI, 2019. 196 p. ill. (Resonemus pariter; 2.) Tart.:1. Kutatástörténet és kodikológiai leírás; 2. A halotti zsolozsma; 3. A himnárium; 4. Öszszegzés, liturgiatörténeti összegzések: 13-63.

A kötet tartalma angol (65-121.) és horvát nyelven (123-175.)

Szoliva Gábriel: Secunda pars breviarii - A 13. századi esztergomi breviárium kottás szanktoráléjának rekonstrukciója felé $=$ MKsz (135.) 2019. 3. 307-330. ill. https://doi.org/10.17167/ mksz.2019.3.307-330

SzoLIVA Gábriel: Két középkori magyarországi kottás pszaltériumtöredékről = MKsz (135.) 2019. 3. 398-399. https://doi.org/10.17167/mksz.2019.3.398-399

Az MTA KIK Kézirattára T 14 és T 285 jelzetü fragmentumáról

TAKÁCs Levente: A magyar földmérés(i irodalom) kezdetei és az ókori hagyomány = Hunyadi Mátyás és kora / szerk. BÁRÁNY Attila et al. Debrecen: MTA-DE Lendület „Mo. a középkori Európában” Kutcsop., 2019. 24-33.

Az OSZK Cod. Lat. 197. jelzetü kéziratáról

Uhrin Dorottya: Az ún. I. és II. esztergomi zsinat és a Pray-kódex = Írások a Pray-kódexről...19-28.

VRABÉLY Márk: Frater F. müveltsége. Mária-csodák a Kazinczy- és a Tihanyi kódexben $=$ Sic itur ad astra (68.) 2019. 143-172. 285.

\section{Nyomda-, nyomdászattörténet}

BÁNFI Szilvia: A fiumei nyomdászat kezdetei $=$ MG (63.) 2019. 5. 66-69 ill.

BáNYAI Réka - ECSEDY Judit, V.: A Váradi Biblia címlapvariánsai = MKsz (135.) 2019. 3. 385-397. https://doi.org/10.17167/mksz.2019.3.385-397 
Bordé Katalin: A Jóba Nyomda útja a felemelkedéstől az elárverezésig = Szabolcs-Szatmár-Beregi Szle (54.) 2019. 1. 3-22. ill.

ECSEDY Judit, V.: Reformáció és könyvnyomtatás. A protestáns nyomdák helyzete = Ige-idők. A reformáció 500 éve. Magyar Nemzeti Múzeum, 2017. április 26 - november 5. / szerk. KIss Erika, ZÁszKalicZKy Márton, ZászKaliczKy Zsuzsanna; térk. NAGy Béla. Bp.: MNM, 2019-. Tanulmányok. 122-132. ill.

KIs Krisztián Bálint: Szatmár vármegye nyomdászata = MG (63.) 2019. 1. 66-70. ill.

SimON Melinda: Kiadói és nyomdászjelvények Magyarországon 1901-1920 = Hungarian printers' and publishers' devices 1901-1920. Bp.: OSZK, 2019. 252 p. ill.

SimON Melinda: Magyarországi kiadók és nyomdászok jelvényei 1901-1920 között = Kiadói és nyomdászjelvények Magyarországon, 1901-1920 = Hungarian printers' and publishers' devices 1901-1920. / Simon Melinda. Bp.: OSZK, 2019. 7-15. ill.

Bevezető tanulmány

Angol nyelven: 17-26.

Simon Melinda: Hungarian printers' and publishers' devices between 1901-1920 = Kiadói és nyomdászjelvények Magyarországon, 1901-1920 = Hungarian printers' and publishers' devices 1901-1920. / Simon Melinda. Bp.: OSZK, 2019. 17-26. ill.

A kötet bevezetö tanulmánya angol nyelven

Magyar nyelven: 7-15.

\section{Könyvmúvészet, illusztráció, ex libris}

BÁNFI Szilvia: A sokszorosított grafika szerepe Raphael Hoffhalter tipográfus tevékenységében = MüvtörtÉrt (68.) 2019. 1/2. 5-31. ill. https://doi.org/10.1556/080.2019.00001

BoreczKy Anna: Classical Protagonists - Medieval Postures. Body Language in early Medieval Illustrations of Late Antoque Texts $=$ Acta historiae artium Academiae Scientiarum Hungaricae 60. 2019. 29-49. ill. https://doi.org/10.1556/170.2019.60.1.2

Az OSZK Cod. Lat. 4. jelzetü dokumentumáról

BorECZKY Anna: Apollonius pictus Reevaluated. Kurt Weitzmann's Legacy and the Multilayered Historicity of Medieval Manuscripts = After the Carolingians. Re-defining manuscript illumination in the 10th and 11th centuries / ed. by Beatrice Kitzinger, Joshua O'Driscoll. Berlin, de Gruyter,2019.(Sense,Matter,andMedium;2.)433-457.ill.https://doi.org/10.1515/9783110579499015

Az OSZK Cod. Lat. 4. jelzetű kéziratáról

BoreczKy Anna: Kelet és nyugat között. A Pray-kódex képsora In: Írások a Pray-kódexről... 2945. ill.

BorossAy Katalin: Tarnóczy István Szent László életrajza metszetábrázolásainak szöveges forrásai = Szent László kora és kultusza. Tanulmánykötet Szent László tiszteletére / szerk. KERNY Terézia, Miкó Árpád és Sмонау András; mutatókat kész. PÁszTor Katalin. Székesfehérvár: Székesfehérvári Egyházm. Múz, 2019. 102-161. 296. ill.

FÁBián Dénes Zoltán: Biczó Géza. Festőművész- rajztanár, 1853-1907. Kiskunhalas: Thorma J. Múz.-Halasi Múz. Alapítvány, 2019. 140 p. ill. (Thorma János Múzeum könyvei; 44.)

A Vasárnapi Újság illusztrátora

PAPP Júlia: II. Lajos halálának és holtteste megtalálásának ábrázolása 17. század végi könyvillusztrációkon $=$ Ars Hungarica (45.) 2019. 4. 451-462. ill. 
PAPP Júlia: Egy 15. század végi illusztráció „újrahasznosítása” a mohácsi csatáról tudósító német hírlevelekben = MKsz (135.) 2019. 3. 366-384. ill. https://doi.org/10.17167/mksz.2019.3.366384

PAPP Júlia: Az 1526. évi mohácsi csata 16-17. századi képzőmủvészeti recepciója = Több mint egy csata: Mohács. Az 1526. évi ütközet a magyar tudományos és kulturális emlékezetben / szerk. FodOR Pál és VARGa Szabolcs SzőTs Zoltán Oszkár közremüködésével. Bp.: MTA BTK, 2019. 149-193. ill.

PAPP Sára Írisz: A láttatás szerepe a 18. századi katolikus metszetolvasásban = Kor/társ. Kapcsolat, háló(zat) és közösség az 1800 előtti Európában. Fiatalok Konferenciája 2018 / szerk. ERDőDI Alexandra Anita et al. Bp.: Reciti, 2019. 141-154. ill.

RÉvÉSz Emese: Firkaforradalom. Válogatott írások a grafikáról. Bp.: Új Mủvészet, 2019. 253 p. ill. A korábban megjelent írások között a szerző grafika-, karikatúra- és plakáttörténeti tanulmányaival

SzILÁRDFY Zoltán: Metszet a Szent László királyt tisztelö bécsi diákság Ürményben örzött latin emlékalbumában $=$ Szent László kora és kultusza. Tanulmánykötet Szent László tiszteletére / szerk. Kerny Terézia, Mikó Árpád és Smohay András; mutatókat kész. Pásztor Katalin. Székesfehérvár: Székesfehérvári Egyházm. Múz, 2019. 162-169. 297. ill.

\section{Kisnyomtatványok}

Boros István: A Patroni menstrui váci „példánya” = Keresztény megújulási mozgalmak... 91116. ill.

ForGÁcs Márton: „Selam min Saraj-Bosna”. Egy különleges szarajevói képeslap a Hadtörténeti Múzeum Kéziratos Emlékanyag-gyüjteményében = Tanulmányok Pollmann Ferenc tiszteletére / szerk. Doмокоs György, KrámLi Mihály, Mészáros Kálmán. Bp.: Krámli M., 2019. 53-57. ill.

KaTONA Anikó: A plakátmüvészet megújulása a Tanácsköztársaság idején. Kiadói szándékok, példányszámok, tendenciák = MủvtörtÉrt (68.) 2019. 1/2. 189-207. ill. https://doi. org/10.1556/080.2019.00007

KNAPP Éva: Újabb ismeretlen XVIII. századi magyarországi nyomtatványok = KF (29.) 2019. 4. 595-601. ill.

MÉREG Martin: Mit üzentek a pécsi aprónyomtatványok az 1848/49-es forradalomról és szabadságharcról? Egy kiállítás forrásanyagának médiatörténeti szempontú vizsgálata = „A hazának hü öre és oszlopa"... 207-222.

SAmu Botond Gergő: Történelem alulnézetböl. Válogatás az Országos Széchényi Könyvtár szöveges plakátjaiból $=$ HadtörtMúzÉrt (19.) 2019. 75-90. ill

\section{Térképészet}

BARTOS-ELEKES Zsombor: Lakatos István 1702-es térképei a székelyekröl = Térképtörténeti közlemények...27-36. ill.

Az OSZK Oct. Lat. 324. jelzetü kéziratáról

DANKU György: Egy ritka töredék. Wolfgang Wissenburg Szentföld-térképe = Térképtörténeti közlemények... 127-131. ill.

Az OSZK Régi Nyomtatványok Tára, Inc. 79. jelzetü ősnyomtatványában található töredékröl

GRóF László: John Speed Magyarország-térképei (1627-1676) =Térképtörténeti közlemények... 9-26. ill. 
MÁRTON Mátyás: Ismeretlen Reguly-térképek és térképvázlatok? Adalékok és kérdések Reguly kartográfiai munkáival kapcsolatban = GeodKart (71.) 2019. 6. 13-17. ill. https://doi.org/10.30921/ GK.71.2019.6.2

PÁszTı László: Ami az Atlas Hungaricusból kimaradt. Ungarn und seine Kronländer = Térképtörténeti közlemények... 132. ill.

ReISz T. Csaba: Lutsch István nemessége = Térképtörténeti közlemények... 37-54. ill. Az OSZK TK 2 077, TK 2 058, és TK 1574 jelzetü térképeiröl Lutsch Istvánra vonatkozó levéltári források szövegközlésével

SAMU Botond Gergő: Első világháborús térképek az Országos Széchényi Könyvtár Térképtárában =Térképtörténeti közlemények... 55-97 ill.

SEGYEVy Dániel Zoltán: Vörös térkép 100. Teleki Pál néprajzi térképének különböző változatai 1919 és 1941 között $=$ Térképtörténeti közlemények... 99-125.ill.

Térképtörténeti közlemények. 3. Az Országos Széchényi Könyvtár Térképtárának évkönyve 2018./ főszerk. Pászti László. Bp.: OSZK, 2019. 132 p. ill.

\section{Papír}

Mór György: Temerini elbocsátólevelek vízjelei, 1840 = MVízjel (17.) 2019. 46. 9-11. ill.

PeLBÁRT Jenő: Besztercebánya-1. papírmalom koronás magyar címer-vízjele az 1766-1778 közötti időszakból = MVízjel (17.) 2019. 47. 20. ill.

PelBárt Jenő: Besztercebánya-2. papírmalom koronás-pajzsos postakürt-vízjele 1818-ból = MVízjel (17.) 2019. 46. 12. ill.

PeLbárT Jenő: Dejte papírmalom várkapus vízjele, 1873 = MVízjel (17.) 2019. 46. 19. ill.

Pelbárt Jenő: Ebergassing-Franzenstahl papírmalom vízjelpárja 1792-ből = MVízjel (17.) 2019. 48. 29. ill.

PeLBÁRT Jenő: Eibenschütz (Ivančice) papírmalom koronás magyar címer-vízjele 1788-ból = MVízjel (17.) 2019. 48. 28. ill.

Pelbárt Jenő: Felka papírmalom új papíralak-vízjele, 1845-1846= MVízjel (17.) 2019. 48. 27. ill. Pelbárt Jenő: Gács papírmalom griff-telamonos vízjelpárja = MVízjel (17.) 2019. 46. 17-18. ill.

Pelbárt Jenő: Az iglói Schertl testvérek név-vízjele 1809-ből = MVízjel (17.) 2019. 49. 24. ill.

PelbáRT Jenő: J. Hadaun koronás magyar címer-vízjele 1805-ből = MVízjel (17.) 2019. 49. 25-26. ill.

PELBÁRT Jenő: Kis Tivadar pápai papírkereskedő szecessziós monogram-és név-vízjele 1896-ból = MVízjel (17.) 2019. 46. 13. ill.

PelBáRT Jenő: Leiben papírmalom koronás magyar címer-vízjelei, 1791-1792 = MVízjel (17.) 2019. 49. 27-28. ill.

Pelbárt Jenő: Mohelno papírmalom magyar címeres vízjelpárja 1805-ből = MVízjel (17.) 2019. 48. 30. ill.

Pelbárt Jenő: Név-vízjelek. 4/3. rész. Papírmalom név-vízjelek= MVízjel (17.) 2019. 46. 31-50. ill.

PelbáRT Jenő: Név-vízjelek. 4/4. rész. Papírmalom név-vízjelek= MVízjel (17.) 2019. 47. 31-50. ill.

PelbárT Jenő: Név-vízjelek. 4/5. rész. Papírmalom név-vízjelek= MVízjel. (17.) 2019. 48. 31-50. ill.

PelbárT Jenő: Név-vízjelek. 4/6. rész. Papírmalom név-vízjelek = MVízjel (17.) 2019. 49. 29-50. ill.

PeLBÁRT Jenő: Svedlér papírmalom három új vízjele az 1787-1825 közötti időszakból = MVízjel (17.) 2019. 46. 5-7. ill.

Pelbárt Jenő: Svedlér papírmalom új, monogramos papírmalom név-vízjele 1799-ből = MVízjel (16.) 2018. 45. 15. ill.

PelbárT Jenő: Swidnitz papírmalom koronás magyar címer-vízjelei a magyar anyagban az 17931837 közötti időszakból = MVízjel (17.) 2019. 48. 11-22. ill. 
PeLbárt Jenő: Újlehota-1. papírmalom vízjelpárja, 1807 = MVízjel (17.) 2019. 47. 26. ill.

PelbáRt Jenő: Vélographe levélpapír-vízjel 1913-ból = MVízjel (17.) 2019. 46. 14. ill.

A francia levélpapír-vízjelet az amszterdami F. L. Esman cég Budapestre küldött fejléces hivatali levele tartalmazza

PeLbÁRT Jenö: Vöröskő papírmalom címer-vízjelváltozatai az 1822-1845 közötti időszakból = MVízjel (17.) 2019. 46. 15-16. ill.

Pelbárt Jenő: World Bank Paper levélpapír-vízjel, 1931 = MVízjel (17.) 2019. 46. 8. ill.

PelbáRt Jenő- Mór György-Buncsák Katalin Julianna: Adatok Nova Villa (Nova Ves) papírmalom vízjeleihez = MVízjel (17.) 2019. 47. 3-19. ill.

Pelbárt Jenő-Mór György-Buncsák Katalin Julianna: KAZ-vízjelek. 2. Európai és magyar papírmalmok vízjelei az 1732-1789 közötti időszakból = MVízjel (17.) 2019. 47. 27-30. ill.

Pelbárt Jenö-MóR György-Buncsák Katalin Julianna: KAZ-vízjelek. 3. rész. Európai és magyar papírmalmok vízjelei az 1776-1789 közötti időszakból = MVízjel (17.) 2019. 48. 3-10. ill.

\section{Könyvkötés-történet}

BernáD Rita Magdolna-Muckenhaupt Erzsébet: Pázmány Péter dedikált prédikációskönyve a székelyszenttamási plébánia régi könyvtárában 1. = Lustra (6.) 2019. 2. 13-17. ill.

Az RMNy 1659. tételének eddig ismeretlen példányáról

LAUF Judit: Budai reneszánsz kötéstáblából előkerült ősnyomtatvány-töredékek. A Lányi-kódex kötéscsaládja és a budai könyvkereskedők $=$ MKsz (135.) 2019. 3. 331-345. https://doi. org/10.17167/mksz.2019.3.331-345

Az OSZK Ant. 7980 jelzetü példányának kötéséről

RozSONDAI Marianne: A magyar könyvkötés a gótikától a művészkönyvekig.

Bp.: MTA KIK-Kosssuth K., 2019. 540 p. ill. + mell. (47 p. ill.)

Tóтн Zsuzsanna: Corvina-kötések az Országos Széchényi Könyvtár gyüjteményében = Isis. Erdélyi magyar restaurátor füzetek. 19. 2019. 7-18. ill.

Veres Anna Mária: Aspecte din viața institului Ráday din Budapesta. Circulația și legătura cărţilor din fabuloasa sa bibliotecă = Sargetia 9. 2018. 305-314.

\section{Könyvkereskedelem, -terjesztés}

BÉRES Norbert: „Roman und was besser ist, als Roman”. Über die Vertriebsstrategien des Romans $=$ Media and literature... 221-232.

\section{Kiadástörténet}

\section{Több évszázadot érintö munkák}

FrAUHAMMER Krisztina: Imakönyvek, imafüzetek az Oltáriszentségröl Eucharisztia és úrvacsora a magyarországi vallási kultúrában 1. / FÁBIÁN Gabriella közremüködésével szerk. BARNA Gábor. Szeged: MTA-SZTE Vallási Kultúrakut. Csop., 2019. 162-175.

A Függelékben az Oltáriszentség tiszteletére kiadott imakönyvek és kisnyomtatványok bibliográfiájával (16-20. sz. első fele) 
HubERT Gabriella, H: Gyülekezeti énekek Balassi Bálint és Rimay János Istenes éneki kiadásaiban = Lelkipásztor (94.) 2019. 5. Tanulmányok. 174-176.

SzABó Attila: Debrecenhez kötődő füveskönyvek = Orvostört. Közl. (69.) [!64.] 2018. 1/4. 61-69.

\section{5. század}

SChMelCZER-PoháNKa Éva: A Pécsi Misekönyv második kiadásának pannonhalmi példánya = Collectanea Sancti Martini 7. 2019. 67-84. ill.

SCHMELCZER-PohÁNKA Éva: A Pécsi Missale két kiadásának fennmaradt példányai és helyi jelentőségük $=$ KF (29.) 2019. 3. 431-443.

16. század

BAJÁKı Rita: Kompiláció 16. századi imakönyveinkben = Átfedések... 69-77. ill. Az RMNy 470., 289., 732., és az RMNy 395., 353. tételeiröl

Csepregi Zoltán: Die Rezeption der Trienter Dekrete in der evangelisch-reformierten Bekenntnisschrift Confesssio Catholica von Debreczin-Erlau 1562 = Das Trienter Konzil und seine Rezeption im Ungarn des 16. und 17. Jahrhunderts. [...eine Tagung ... vom 7. bis 9. October 2013 an der Katolischen Péter Pázmány Universität in Budapest...] / Márta FATA et al. Hgg. Münster: Aschendorff, 2019. 47-61.

Az RMNy 176. és RMNy 177. tételéröl

HUBERT Gabriella, H.: Az keresztyéni gyülekezetben való isteni dicséretek. Bártfa $1593=$ Az kereztieni gievlekezetben valo isteni diczéretek egyben szedegetettet, vyonnan nyomtatatot, émendáltatot, és sok szép dicziretteckel megöregbitettet / [...] közzéteszi KöszeGHY Péter. Bp.: Balassi-OSZK-MTA BTK ITI, 2019. Hasonmás kiad. 7-70.

Az RMNy 713. kötetéröl

Az kereztieni gievlekezetben valo isteni diczéretek egyben szedegetettet, vyonnan nyomtatatot, émendáltatot, és sok szép dicziretteckel megöregbitettet / [...] közzéteszi KöszeGHY Péter. Bp.: Balassi-OSZK-MTA BTK ITI, 2019. Hasonmás kiad. 430 p. ill. + mell. (69 p.). - (Bibliotheca Hungarica antiqua; 47.)

A mellékletben H. Hubert Gabriella tanulmányával

LAUF Judit: Magyar nyelvemlékszövegek egy 16. század eleji pálos misekönyvben = MKsz (135.) 2019. 1. 18-35. https://doi.org/10.17167/mksz.2019.1.18-35

Az OSZK RMK III 196/2 jelzetű kötetéröl

LÁzÁR István Dávid: A kolozsvári jezsuita iskola megnyitására kiadott tézisek (1581) = Antikvitás \& reneszánsz (2.) 2019. 3. 183-208. https://doi.org/10.14232/antikren.2019.3.183-208

A latin nyelvü tézisek szövegközlésével

NÉMETH Áron: Az Ószövetség költöi-tanítói és prófétai könyvei a Heltai-féle Bibliában = Szent Biblia / Heltai Gáspár és mtársai fordításában; [...] ÖTvös László [...] gondozásában. Debrecen: Ötvös László; Bp.: OSZK, 2019. Hasonmás kiad. 2. köt. 2005-2013.

Az RMNy 92., 95., 96., 162. tételeirö1

NÉMETH Áron: Az Ószövetség történeti könyvei a Heltai-féle Bibliában = Szent Biblia / HeLTAI Gáspár és mtársai fordításában; [...] ÖTvös László [...] gondozásában. Debrecen: Ötvös László; Bp.: OSZK, 2019. Hasonmás kiad. 1. köt. 1571-1580.

Az RMNy 90., 208. tételeiröl

SzABó András: Két ismeretlen wittenbergi verseskötet a 16. század végéről = A reformáció és a katolikus megújulás latin nyelvü irodalma / szerk. BÉKÉs Enikő et al. Bp.: MTA BTK ITI, 2019. 105-111. 
Szent Biblia / HeLtaI Gáspár és mtársai fordításában; [...] ÖTvös László [...] gondozásában; NÉMETH Áron [...] kísérő tanulmányával. Debrecen: Ötvös László; Bp.: OSZK, 2019. Hasonmás kiad. 3 db. (Nemzetközi Teológiai Könyv; 91.). [1. köt.] Az Ószövetségi [!Ószövetség] történeti könyvei. 1592 p.; [2. köt.] Költői és prófétai könyvek. 2024 p.; [3. köt.] Újszövetségi könyvek, 1562 / Borsa Gedeon, Perger Péter kísérö tanulmányával. 1104 p.

Borsa Gedeon és Perger Péter tanulmánya első megjelenési adatai: MKSz (122.) 2006. 2. 121145.

Szoliva Gábriel: „Ad laudem et gloriam Dei optimi maximi”. Psalterium Strigoniense. Surviving from the Viennese Residence of Nicolaus Olahus $=$ Nicolaus Olahus, 450. Tagungsband der internationalen Konferenz zum 450. Todestag von Nicolaus Olahus / Hrsg. von Emőke Rita SzILÁGYI.Wien: Inst. für Ungarische Geschichtsforschung in Wien; Bp.: Inst. für Literaturwissenschaft, Geisteswissenschaftliches Forschungszentrum der Ungarischen Akademie der Wissenschaften, 2019. 97-105.

16-17. század

TÚRI Klaudia: Calendarium Novum - Moments from the Adapting Process of the Gregorian Reform in Hungary = Kniha (Martin,Slovenská Národná Kniznica) 2019. 38-45. ill.

Az RMNy 529., 530., 2724. jelzetű nyomtatványokról

17. század

BAKONYI Zsuzsanna: „Imploy your sword rather than waste your youth in gaming-houses!”. Count Taaffe's letters from the Imperial Camp in 1683 = Kniha. (Martin,Slovenská Národná Kniznica) 2019. 46-53. ill.

ETÉNYI Nóra, G.: Erdély politikai imázsa a Német-római Birodalom propagandájában a harmincéves háború idején = Politikai nyelvek a 17. század első felének Magyarországán / szerk. KáRMÁN Gábor, ZásZKalıcZKy Márton. Bp.: Reciti, 2019. 285-326. ill.

FeKete Csaba: Hodászi tételei (1610) = MKsz (135.) 2019. 1. 91-94. https://doi.org/10.17167/ mksz.2019.1.91-94

Megjegyzések az RMNy 1009 leírásához

Hevesi Andrea: Az Újfalvi-féle énekeskönyvek hatása a 17. századi unitárius énekgyüjteményekre = Újfalvi Imre pere és műveltsége...146-159.

Hubert Gabriella, H.: Újfalvi Imre 1602-es énekeskönyvének szövegei = Újfalvi Imre pere és müveltsége...137-145.

Az RMNy 886. kötetröl

KovÁcs Eszter: Néhány érdekes példa a cseh és a magyarországi lelkiségi irodalom átfedéseire a 17. század végéről = Átfedések...139-144.

OLÁH Róbert: Hodászi Lukács zsinati vizsgatételeinek hasonmása = Újfalvi Imre pere és műveltsége...163-174. ill.

A Teleki-Bolyai Könyvtár Tq-1564 kolligátumának negyedik darabjáról (RMNy 1009)

Hodászi Lukács Assertiones... címmel kiadott (RMNy 1009) nyomtatványának hasonmás kiadásával

PAPP Ingrid: A Praxis pietatis cseh nyelvű fordítása = ItK (123.) 2019.5. 621-638.

A Praxis pietatis Comenius által fordított kiadásairól (RMNy 1702 ; RMNy 1906) és Medgyesi Pál fordításáról

RÉGER Ádám: Bünbánati zsoltárok Vásárhelyi Gergely Canisius-fordításában=Átfedések...105-114. 
SzEBELÉDI Zsolt: Ábrahám Szenci Kertész and Versus sententionales = Kniha. (Martin, Slovenská Národná Kniznica) 2019. 127-130.

Az RMNy 3242 jelzetü kiadvány második müvéről

То́тн Gergely: Nádasdy Ferenc, Révay Péter müveinek kiadója $(1652,1659)$. Történelmi érdeklödés, imázsépítés, vagy politikai tett? = Háborúk, alkotások, életutak. Tanulmányok a 17. század közepének európai történelméről / szerk. NAGY Gábor, VISKOLCZ Noémi. Miskolc: Miskolci Egy. K., 2019. 150-171.

VARGA Lajos: Az Atlas Marianus teológiai háttere, teológiatörténeti előzményei, jelentősége a Trienti zsinat utáni megújulásban és magyarországi vonatkozásai = Keresztény megújulási mozgalmak...67-83. ill.

18. század

AJKAY Alinka: Nepomuki Szent János tisztelete a XVII-XVIII. = Keresztény megújulási mozgalmak... 85-90.

FAZAKAS Gergely Tamás: Árva Bethlen Kata önreprezentációi. Érvek az önéletírás filológiai szempontú, kontextualizáló olvasása mellett $=$ Studia litteraria (58.) 2019. 3/4. 38-58.

Hegedüs Béla: Literary History as an Argument for the Existence of Literature. Miklós Révai's Call in Magyar Hírmondó and Költeményes Magyar Gyüjtemény = Media and literature... $165-179$.

A tanulmány magyar nyelven megjelent: Doromb 2018. 6. 101-112. 135.

MAczÁK Ibolya: Megerősített bátorság: Padányi Biró Márton és diétai prédikációi = Személyek, intézmények...77-86.

SÁNTA Sára: Az első magyar városmonográfia kiadása Schönvisner István és Szily János levelezésének tükrében = MKsz (135.) 2019. 2. 202-218. ill. https://doi.org/10.17167/mksz.2019.2.202-218

SzÉKeLY Gábor: Telek József kecskeméti prédikációi a kalocsai érseki nyomdából = Személyek, intézmények... 153-164.

То́тн Gergely: The first edition of Nicolaus Olahus' Hungaria in Matthias Bel's Adparatus (1735) = Nicolaus Olahus, 450. Tagungsband der internationalen Konferenz zum 450. Todestag von Nicolaus Olahus / Hrsg. von Emőke Rita SzILÁGYI. Wien: Inst. für Ungarische Geschichtsforschung in Wien; Bp.: Inst. für Literaturwissenschaft, Geisteswissenschaftliches Forschungszentrum der Ungarischen Akademie der Wissenschaften, 2019. 123-142.

VERóK Attila: Lelki fegyverház és Lelki iskola - Lelkiségi könyvek kiadása mint kiemelt föpásztori feladat Egerben (1755-1799) = Személyek, intézmények...213-228.

VitusKa Virág: Faicser Ferenc Encomionja Klimo György püspökhöz = „A hazának hű őre és oszlopa”... 145-158.

18-19. század

BÉRES Norbert: Eltérő sorozatkoncepciók a klasszikus századfordulón - két példa = „Közöttünk a' mester"... 179-188.

KnAPP Éva: Martin von Cochem Magyarországon. Zebegény: Borda Antikvárium, 2014-. 3. rész. Pótlások és kiegészítések a második részhez, Baumgarten, VI. Pius pápa imádságos könyve. 2019. 187 p. (Régi magyarországi vallásos nyomtatványok; 4.)

SzELESTEI NAGY László: Magyar nyelvű szentmiseszöveg-fordítások a 18-19. században = Magyar Sion (13.) 2019. 1. 99-114.

A mellékletben a nyomtatásban magyarul megjelent teljes szentmisefordítások (1763-1900) bibliográfiai adataival 
19. század

DoNCSECZ Etelka: „Mivel én nem olly ártatlanúl viseltem a’ fogságot...”. Verseghy Ferenc és az udvari propaganda. = „Közöttünk a’ mester”... 189-196.

Pedro Cevallos Napóleon ellenes röpirata magyar fordításának keletkezési körülményeihez

Kecsmár Szilvia: Czóbel Minka és a Lélekvándorlás. A mü fordításának és megjelentetésének körülményei a Polignac-levelekben = Nőszerzők a 19. században... 221-233.

Klem Dénes- Mizera Tamás: „Majd ha énektanításnál a kezdet nehézségein keresztül-vergödünk...”. Zsasskovszky Ferenc és Endre Egri ének-kátéja kiadástörténeti és zenepedagógia-történeti összefüggésben $=$ „A tudomány ekként rajzolja világát”. Irodalom, nevelés és történelem metszetei I. Tanulmánykötet. Az Eszterházy Károly Egyetem Doktorandusz Önkormányzata, az Eötvös Loránd Tudományegyetem Doktorandusz Önkormányzata és a Doktoranduszok Országos Szövetsége Irodalomtudományi Osztály I. közös konferenciájának tanulmánykötete / szerk. Fodor József Péter, Mizera Tamás, Szabó P. Katalin. Eger: EKE Doktorandusz Önkormányzat; Bp.: ELTE EDÖK - DOSZ Irodalomtudományi Oszt., 2019. 148-161.

19-20. század

PoGÁNY György: A Franklin-Társulat Magyar Irodalmi Intézet és Könyvnyomda Rt. és ifjúsági kiadványai 1873-1945 = KN (21.) 2019. 3/4. 84-125.

\section{Sajtótörténet}

18. század

Lengyel Réka: The Newspaper as a Medium for Developing National Language, Literature, and Science. Mátyás Rát and the Magyar Hírmondó between 1780 and $1782=$ Media and literature... 87-100.

VADERNA Gábor: Város és pallérozódás. A Mindenes Gyüjtemény eszmetörténeti helyéhez $=$ ItK (123.) 2019. 4. 476-489.

18-19. század

ANTAL Alexandra: A siker aspektusa a bécsi Magyar Hírmondóban $=$ „Közöttünk a’ mester”... 171-178.

BALOGH Piroska: Johann Ludwig Schedius's Literärischer Anzeiger and the Tradition of Critical Journalism in the Hungarian Kingdom around 1800 = Media and literature... 207-220.

Csörsz Rumen István: The Literary Program of István Sándor and the Periodical Sokféle (17911808) = Media and literature... 143-154.

A tanulmány magyarul megjelent: ItK, 122. (2018) 6. 757-767.

FRIED István: Mehrsprachigkeit in den ersten Jahrzehnten der ungarischen Zeitschriftenliteratur = Media and literature... 19-40.

Media and literature in multilingual Hungary, 1770-1820 / ed. by Ágnes DóBÉK, Gábor MÉszÁRos and Gábor VADERnA. Bp.: Reciti, 2019. 285 p. (Reciti conference books; 3.)

A Györött és Pannonhalmán, 2018. ápr. 25-27. között rendezett konferencia előadásainak szerkesztett anyaga 
19. század

Hudi József: „Politikába nem avatkozunk...”. Egy pápai lapszerkesztő mozgástere a kiegyezés korában = Szélesvíz (6.) 2019. 2. 29-32. ill.

Kocsis Lajos: A Csíki Lapok politikai lappá alakulása, 1897 = A Csíki Székely Múzeum évkve. 2019. 123-133.

KRIZSÁn Bálint: A Nemzeti Ujság politikai állásfoglalása és a márciusi fordulat, 1845-1848= Belvedere Meridionale (31.) 2019. 2. 123-135. https://doi.org/10.14232/belv.2019.2.7

NóвIK Attila: A pedagógiai szaksajtó és a néptanítói szakmásodás a dualizmus korában. Szeged: SZEK JGYFK, 2019. 95 p.

Sajtótörténet: $41-81$.

PeTő Bálint: A helyi sajtó megerősödése egy dél-alföldi városban. A Szentesi Lap első évei (18721883) = Délvidéki Szle (5.) 2018. 2. 18-31.

PeTő Bálint: Kérészéletű hetilapok Szentesen az 1870-es években = Nemzetiségek, vallások, kultúrák a Dél-Alföldön / szerk. MikLós Péter. Szeged: BSÖ Alapítvány, 2019. 117-128.

PeTő Bálint: A szentesi sajtó kezdetei, 1871-1883. Szeged: Szegedi Egy K.-JGYF K., 2019. 221 p. ill.

SCHÖвERL Miklós: Póda Endre városplébános sajtóküzdelmei. A katolikus sajtómozgalom előzményei Sopronban és az Oedenburger Volksblatt = Soproni Szle (73.) 2019. 2. 207-229. ill.

19-20. század

DEDE Franciska: A Hét et la France. Influences et présences françaises dans les vingt premières années de la revue $=$ Revue d'études françaises. 23. (2019). 46-61.

KLESTENITZ Tibor: Katolikus és protestáns sajtótörekvések Magyarországon. Hasonlóságok és különbségek, 1890-1918 = Laborator assiduus. A 70 éves Zombori István köszöntése / szerk. SomorJai Ádám, Somorjai Gabi. Bp.: MTA BTK TTI-MNL Orsz. Lvt., 2019. 263-270.

20. század

A Budapesti Ujságírók Almanachja 1908-ra. A Magyar Bohémvilág/ szerk. SzERDAHELYI Sándor; kísérő tanulmány SzÉNÁSI Zoltán, WIRÁGH András. Repr. kiad. Bp.: OSZK - Argumentum K., 2019. ill.

Az eredeti kiadás megjelenési adatai: Bp.: Budapesti Újságírók Egyesülete, 1908.

Döвör András: A Kanizsai Újság és a Kanizsai Ellenőr közéleti és bulvárhíreinek statisztikai elemzése = Délvidéki Szle (5.) 2018. 2. 32-52.

DöвöR András: Tömegkultúra és „,pulitzeri fordulat” a délvidéki magyar sajtóban. Nemzetiségek, vallások, kultúrák a Dél-Alföldön / szerk. MıкLós Péter. Szeged: BSÖ Alapítvány, 2019. 117128.

KLESTENITZ Tibor: Katolikus sajtó és nyilvánosság a második világháború éveiben = Útkeresés két korszak határán. A Katolikus Szociális Népmozgalom 75. évfordulójára / szerk. KLESTENITZ Tibor, Petrás Éva, Soós Viktor Attila. Agyagosszergény: Közi Horváth J. Népfőisk., 2019. $39-52$.

OLASz Lajos: Sajtóirányítás és háborús propaganda az I. világháború időszakában $=$ Belvedere Meridionale (31.) 2019. 2. 104-122. https://doi.org/10.14232/belv.2019.2.6

Orosz László: A ,zsidó sajtóhegemónia” elleni küzdelem a hazai német mozgalom sajtójának korai időszakában (1917-1920) = KEK (12.) 2019. 1. 183-198. 
Pardon... Az Új Nemzedék rovata Kosztolányi Dezső szerkesztésében, 1919-1921 / szerk. ARANY Zsuzsanna. Bp.: Osiris, 2019. 373 p.

Arany Zsuzsanna tanulmányával: 7-58.

Sipos Balázs: Hogyan lett az újságírás női hivatás is Magyarországon? = A női kommunikáció kultúrtörténete Tanulmányok / szerk. Sipos Balázs, KRÁsz Lilla. Bp.: Napvilág, 2019. 167-184. ill.

Tóтн Orsolya: A Hadimúzeumi Lapok (1925-1927) és a Historia (1928-1932) folyóiratok = HadtörtMúzÉrt, 2018. Különszám, 100. 105-116. ill.

A Hadimúzeumi Lapok repertóriuma: 125-130.

A Historia repertóriuma: 131-144.

ZÁvodSZKY Géza: A kolozsvári alma matertől a Magyar Nemzet rostrumáig. Pethő Sándor (18851940). Pécs: Kronosz; Bp.: MTT, 2019. 352 p. ill. (Sziluett)

\section{Sajtótermékek mint forrásanyagok}

BARÁT Bence: A sport mint honvédelem? A Nemzeti Sport háborús propagandája a második világháború idején = Jel-kép 2019. 3. 54-66. ill.

Biró Annamária: Siebenbürgische Präsenz in der Presse Westungarns. Die Korrespondenten Johann Seivert und József Benkő In: Media and literature...101-122.

A tanulmány magyar nyelven: Acta Historiae Litterarum Hungaricarum 34. 2018. 199-220.

Bogoly József Ágoston: Temesvár és Arad emlékezete 1890-ből. Sajtótörténeti városemlékezet-kutatás $=$ Nemzetiségek, vallások, kultúrák a Dél-Alföldön / szerk. MıкLós Péter. Szeged: BSÖ Alapítvány, 2019. 167-184.

BокоR Zsuzsa: „A mi kis világunk” - a kisebbségi nöiség vizuális reprezentációja a két világháború közötti erdélyi magyar keresztény sajtóban = Me.dok (14.) 2019. 1. 69-87. ill.

CsiszÁr Gábor-TAKÁcs Judit: Nemiszerepáthágás- és homoszexualitás-reprezentációk Az Est 1933-as évfolyamában = Az érzelmek története. A Hajnal István Kör Társadalomtörténeti Egyesület 2017. évi gyöngyösi konferenciájának tanulmánykötete / szerk. LuKÁcs Anikó, TóTH Árpád. Bp.: Hajnal I. Kör Társadalomtört. Egyes., 2019. 423-434. 554.

Az érzelmek története c. 2017. augusztus 31-szeptember 2. között Gyöngyösön megrendezett konferencián elhangzott elöadás kiegészített, szerkesztett változata

Csontos Nóra: A nő konceptualizációja a Protestáns Szemlé-ben = Protestantizmus, identitás és hagyomány a nyelvben / szerk. BöLCSKEI Andrea. Bp.: KRE- L’Harmattan, 2019. 63-71.

DóвÉк Ágnes: Reports on European Publishing Culture in the Journals of Western Hungary = Media and literature...243-251.

Fedoszov Júlia: Liszt Ferenc a 19. századi magyar élclapokban $=$ Ferenc Liszt in the humorous papers of the 19th century = Liszt magyar szemmel 2019. 38. 32-39. ill.

Bilingvis (magyar-angol nyelvü) tanulmány

GeBAuER Hanga: Felvételek a Tengerentúli országokból. Kultúraközvetítés és propaganda a Katolikus Missziók képhasználatában = KET. Kultúrák és etnikumok találkozása. Dimenziók 2. 1 szerk. Lendvai Timár Edit et al. Bp.: Martin Opitz K., 2019. 217-230. ill.

A Dimenziók 2. Kultúrák és etnikumok találkozása c. 2018. május 10-11. között megrendezett konferencián elhangzott előadás kiegészített, szerkesztett változata

Gellén József: Gróf Tisza István és a fontolva haladó Debrecen. Különös tekintettel a Magyar Figyelö 1911-1918-i évfolyamaira = Debreceni Szle (27.) 2019. 3. 251-259.

GLÄSSER Norbert: A „királyi szövetséges” izraelita tapasztalata? Főhatalmi rítusok és izraelita felekezeti sajtóhíreik a modernizálódó Magyarországon 1918-ig = Tanulmányok a magyarországi 
zsidóság történetéből / főszerk. GeCsÉNYI Lajos; szerk. FAZEKAS Csaba; közrem. FizIKER Róbert. Bp.: Milton Friedman Egy., 2019. 77-94. ill.

GLÄSSER Norbert-ZIMA András: A revíziós politika zsidó alakváltozásai. Revíziós sajtópropaganda az izraelita felekezeti és mozgalmi lapokban a II. világháború idején = Jel-kép 2019. 3. 27-40. ill.

Granasztói Olga: The Paper Hazai Tudósítások and the Beginnings of the Cult of Monuments Through the Lens of Ferenc Kazinczy's Articles (1806-1808) = Media and literature...155-164.

Ispén Ágota Lídia: A kulturált életmód sajtóreprezentációi a szocializmus első évtizedében. $=$ Ethnographia (130.) 2019. 3. 464-485.

KÉRI Katalin: A nőnevelés-történet képi forrásai = Per aspera ad astra (6. )2019. 1.7-30. ill. https:// doi.org/10.15170/PAAA.2019.06.01.01

Elektronikus dokumentum: https://per-aspera.pte.hu/archivum/2019-1-szam-10.html

Kiss Margit: Magyar Hírmondó and Dictionary Proposals = Media and literature... 181-192.

KLESTENITZ Tibor: 1918 az észak-magyarországi régió egyházi sajtójának tükrében $=1918$. Vég és kezdet / szerk. Gál Máté, PÉTeRfFy Gergely. Eger: Líceum K., 2019. 117-130.

KLESTENITZ Tibor: Bíró Ferenc és A Szív - egy folyóirat a hívek szolgálatában = Az atya gyöngyszemei. Bíró Ferenc SJ születésének 150. évfordulójára / szerk. HaLmI Krisztina és SzŐNYI Szilárd. Kecskemét: Korda, 2019. 148-162. ill.

KLESTENITZ Tibor: Az egyházpolitika mint propaganda. Az iszlám vallás elismerté nyilvánításának tükrében = In medias res (8.) 2019. 1. 57-71.

KonRÁD Miklós: Csalódott zsidók a magyar zsidóság aranykorában $=$ Az érzelmek története. A Hajnal István Kör Társadalomtörténeti Egyesület 2017. évi gyöngyösi konferenciájának tanulmánykötete / szerk. LuKÁcs Anikó, TóTH Árpád. Bp.: Hajnal I. Kör Társadalomtört. Egyes., 2019. 405-421. 559.

Az érzelmek története c. 2017. augusztus 31-szeptember 2. között Gyöngyösön megrendezett konferencián elhangzott előadás kiegészített, szerkesztett változata

Koós Ferenc: Pedagógia a magyar reformkor folyóirataiban. Szigetszentmiklós: Koós F., 2018. $480 \mathrm{p}$.

LENGYEL Nóra: Anyakép a katolikus női sajtóban (1918-1944) = A család egykor és ma 5. / GYöNGYöSsY Orsolya közremüködésével szerk. BARNA Gábor és Kiss Endre. Szeged: SZTE BTK Néprajzi és Kult. Antropológiai Tansz.- MTA-SZTE Vallási Kultúrakut. Csop., 2019. 206-216. ill.

LENGYEL Nóra: „Nemzetmentők és nemzetrontók.” Nőképek az erdélyi katolikus nőmozgalom sajtókiadványaiban (1926-1944) = Múltunk (64.) 2019. 4. 200-239.

NAGYI Enikő Orsolya: Wass-akarattal a zsidók ellen. Antiszemita publicisztika a dési sajtóban a második világháború idején $=$ Me.dok (14.) 2019. 4. 91-99. ill.

NÉMETH Nóra-MARÓTzy Katalin: Építészet és sajtó - a historizmus öt jelentős szakrális építészeti pályázata = Építés-építészettudomány (47.) 2019. 3/4. 289-322. https://doi.org/10.1556/096. 2019.003

NóBIK Attila: A feminizmus megítélése a Néptanítók Lapjában a 20. század elején = Visszhangzó századok. Tanulmányok, ünnepi írások Szabolcs Éva tiszteletére / szerk. BASKA Gabriella, HEGEDÜs Judit, SzABó Zoltán András. Bp.: ELTE PPK-L'Harmattan, 2019. 22-29.

Penke Olga: La société savante de Komárom et le modèle académique dans le Mindenes Gyüjtemény $=$ Aufgeklärte Sozietäten, Literatur und Wissenschaft in Mitteleuropa / hrsg. von Dieter BREuer und Gábor Tüskés, in Zusammenarbeit mit Réka Lengyel. Berlin- Boston: De Gruyter, 2019. 175-188. https://doi.org/10.1515/9783110637649-009

Petнeö Attila: A délvidéki magyarság helyzetéről a Prágai Magyar Hírlap Trianon utáni számaiban = Délvidéki Szle (5.) 2018. 2. 53-62. 
PETő Bálint: Az első világháború kitörése a magyarkanizsai sajtó tükrében = Délvidéki Szle (5.) 2018. 1. 61-72.

SAmu Botond Gergő: A megszállt Lille hétköznapjai. Az Országos Széchényi Könyvtár világháborús gyüjteményének tükrében = Háborús hétköznapok III. Tanulmánykötet / szerk. SALLAY Gergely Pál, TöröK Róbert, Závodi Szilvia. Bp.: HM Hadtört. Int. és Múz.-MKVM, 2019. 9-22. ill.

SzABó Katalin: A nagy háború néhány orvosi szaklap és egy rokkantaknak szóló újság tükrében = Orvostört. Közl. (69.) [!64.] 2018. 1/4. 71-80.

SzABÓ Noémi: Japán a korai magyar sajtóban = Kortárs japanológia. III. / szerk. FARKAS Ildikó, SÁGI Attila. Bp.: KRE- L'Harmattan, 2019. (Károli könyvek. Tanulmánykötet). 73-92.

SzŐTs Zoltán Oszkár: A Századok, a Hadtörténelmi Közlemények és az első világháború 1945 előtt = Háborús hétköznapok III. Tanulmánykötet/ szerk. SALLAY Gergely Pál, TöröK Róbert, ZÁvoDI Szilvia. Bp.: HM Hadtört. Int. és Múz.-MKVM, 2019. 183-200.

TAMÁs Ágnes: Kossuth Lajos megjelenítése karikatúrákon a kiegyezést követõ években (18671875) = Délvidéki Szle (6.) 2019. 1. 105-126. ill.

TAMÁs Ágnes: Választási kampányeszközök vicclapokban (1867-1872) = Emlékeztető (4.) 2019. 3/4. 29-52.

TuRBucz Dávid: Vezérkultusz és háborús propaganda = Jel-kép 2019. 3. 16-26.

TuRBuCz Péter: Marczali Henrik I. világháborúval kapcsolatos nézetei vidéki hadi beszédei, háborús írásai és a sajtó tükrében (1914-1918) = Per aspera ad astra (6.) 2019. 2. 30-51. https://doi. org/10.15170/PAAA.2019.06.02.02

Elektronikus dokumentum: https://per-aspera.pte.hu/archivum/2019-2-szam-13.html

VADAS Henrietta: A Csík vármegyei zsidók sorsa a helyi sajtó tükrében = Tanulmányok a holokausztról / szerk. Randolph L. BraHAM. Bp.: Balassi, 2001- . 10., 2019. 147-194. ill.

VADERNA Gábor: Möglichkeiten der Urbanität in der ungarischen Zeitschrift Mindenes Gyüjtemény = Media and literature... 123-141.

A tanulmány magyar nyelven: ItK (123.) 2019. 4. 476-489.

VÁmos Gabriella: Egy lap a kulturális tömegmozgalom szolgálatában. A Művelt Nép (1950-1956) című folyóirat elemzése = „A tudomány ekként rajzolja világát”. Irodalom, nevelés és történelem metszetei I. Tanulmánykötet. Az Eszterházy Károly Egyetem Doktorandusz Önkormányzata, az Eötvös Loránd Tudományegyetem Doktorandusz Önkormányzata és a Doktoranduszok Országos Szövetsége Irodalomtudományi Osztály I. közös konferenciájának tanulmánykötete / szerk. Fodor József Péter, Mizera Tamás, Szabó P. Katalin. Eger: EKE Doktorandusz Önkormányzat; Bp.: ELTE EDÖK- DOSZ Irodalomtudományi Oszt., 2019. 312-330.

ZIMA András: „Keressük az utat”. Újjáépítés, ifjúságnevelés, zsidó jövőképek a vészkorszak utáni zsidó sajtóban. = A család egykor és ma 5. / GYÖNGYössy Orsolya közremüködésével szerk. BARna Gábor és Kiss Endre. Szeged: SZTE BTK Néprajzi és Kult. Antropológiai Tansz.MTA-SZTE Vallási Kultúrakut. Csop., 2019. 160-168.

ZıмA András: Zsidó közösségi újjáépítési stratégiák a budapesti felekezeti és mozgalmi sajtóban 1945-1948 között = Tanulmányok a magyarországi zsidóság történetéböl / főszerk. GECSÉNYI Lajos; szerk. FazeKas Csaba; közrem. Fiziker Róbert. Bp.: Milton Friedman Egy., 2019. 192-203. 


\section{Könyvtártörténet}

\section{Több évszázadot érintö munkák}

Kiss Péter: Az Egri Főegyházmegyei Könyvtár az ezredfordulóig. Eger: Bródy S. M. és Vár. Kvt., 2019. 211 p. ill.

SALlAi Ágnes-SzABó Ádám: A Teleki család és az Akadémiai Könyvtár Teleki-állományának magyar vonatkozású földtudományi könyvei = MKsz (135.) 2019. 4. 421-468. https://doi.org/10.17167/ mksz.2019.4.421-468

18. század

Formiga, Federica: Traces of Aldus Manutius and his heirs in the public library of György Klimo in Pécs = „A hazának hü őre és oszlopa”... 119-130.

GoRDÁN Edina: Előszó. A dési ferences rendház könyvtára = A dési ferences rendház könyvtárának régi állománya / összeáll. ... GoRDÁn Edina. Bp.: MTA KIK, 2019.VII-LXVI. LXX-LXXV. LXXVI-XXVIII. ill.

Rácz Emese: Előszó = A nagyenyedi Bethlen Kollégium könyvtárának XVIII. századi gyűjteményei / RÁcz Emese. Bp.: MTA KIK, 2019- . VI-LXIII. ill.

18-19. század

GoRDÁN Edina- BoGDAN, Florin: Cărţi romăneşti vechi în colecția bibliotecii documentare „Bethlen Gábor" din Aiud = Libraria. 16./17. 2017/2018. 122-145. ill.

HuRsán Szabolcs: Batthyány-könyvtárak az Akadémiai Könyvtárban = Teleki József... 196-216. ill. https://doi.org/10.36820/MTAKIK.KOZL.2019.TELEKI.6

SAllai Ágnes-SzABó Ádám: Vegytan az Akadémiai Könyvtár alapító állományában = Teleki József... 122-144. ill. https://doi.org/10.36820/MTAKIK.KOZL.2019.TELEKI.4

19. század

HARTVIG Gabriella: Angol irodalom a Szepesy-gyüjteményben = „A hazának hű őre és oszlopa”... 89-101.

„A hazának hü őre és oszlopa”. Szepesy Ignác pécsi püspök emlékezete. Tudomány és kutatás a Klimo Könyvtárban. A 2018. október 4-én rendezett tudományos konferencia tanulmányai / szerk. Méreg Martin, Molnár Dávid, Schmelczer-Pohánka Éva. Pécs: PTE Egyetemi Kvt. és Tudásközp. - Pécsi Egyházmegye, 2019. 237 p. ill. (A Pécsi Egyetemi Könyvtár kiadványai; 17.)

RÁCZKEvy Edit: A Budapesti Királyi Orvosegyesület könyvtárának első külföldi folyóiratai 18371866 között = Orvostört. Közl. (69.) [!64.] 2018. 1/4. 135-154.

SzABó Ádám: Teleki-gyűjtemény az Akadémián : Az Akadémiai Könyvtár alapító állományának története és rekonstrukciója = Teleki József... 2019. 68-121. ill. https://doi.org/10.36820/ MTAKIK.KOZL.2019.TELEKI.3

19-20. század

GALCSIK Zsolt: A Szécsényi Kaszinó és Gazdakör Egylet Könyvtárának története (1838-1947) = Neograd (42.) 2019. 143-174. ill. 
KRÄHLING János -FeHÉr Krisztina-JobBIK Eszter-Kollár Mária: A Mủegyetem középkori építéstan tanszékének címjegyzéke - Oktatásmódszertani és könyvtártörténeti adalékok a magyar építészképzés történetéhez $=$ Architectura Hungariae (17.) 2018. 2. 33-159.

Elektronikus dokumentum: http://arch.et.bme.hu/wpcontent/uploads/epaper/AH_vol17_no2_ pp33-159_KrahlingFeherJobbikKollar/AH_vol17_no2_pp33-159_KrahlingFeherJobbikKollar_.pdf

REDL Károly: 150 éves az Országgyülési Könyvtár = Parlamenti Szle 2019. 1. 121-126.

20. század

SCHMELCZER-PoHÁNKA Éva: A pécsi szerzetesrendi bibliotékák sorsa az 1950-es években = Kapiller Imre emlékkönyv / szerk. Honváth Zita et al. Zalaegerszeg: MNL Zala M. Lvt., 2019. $227-$ 245. ill.

\section{Bibliofília, magánkönyvtárak}

BíRó-BALOGH Tamás: Két újabb kötet József Attila könyvtárából = ItK (123.) 2019. 1. 98-102. ill. Csorba Dávid: A gályarabok könyvei. Rimaszombati Kies János kötete =Egyháztört. Szle (20.) 2019. 1. 167-172.

A Sárospataki Református Kollégium Tudományos Gyüjteményei. Nagykönyvtár S. 976. jelzetü kötetéről

GoRDÁN Edina: Ifj. Teleki József (1701-1729) disszertációgyűjteménye = A ,recepta religiók” évszázadai Erdélyben. Egyháztörténeti tanulmányok / szerk. KolumBáN Vilmos József. Kolozsvár: Kolozsvári Prot. Teol. Int., 2019. 132-166.

HegYi Ádám: Einleitende Studie. Hungarica in der Dissertationssammlung des Nürnberger Naturforschers und Arztes Christoph Jacob Trew $=$ Hungarica in der Dissertationssammlung des Nürnberger Naturforschers und Arztes Christoph Jacob Trew (1695-1769). Katalog. 15821765 / zgest. und eingel. von Ádám Hegyi. Bp.: MTA KIK, 2019. 6-29. ill.

KREUTZER Andrea: Lövések a könyvtárban = HadtörtMúzÉrt, 2018. Különszám, 100. 223-246. ill. Mezey Mónika: Giovikának régi nagy barátsággal... Dedikált kötetek Honti János könyvtárában = MKsz (135.) 2019. 4. 469-481. ill. https://doi.org/10.17167/mksz.2019.4.469-481

OLÁH Róbert: Alvinczi Péter postillái I. Rákóczi György tábori könyvtárában = MKsz (135.) 2019. 2. 230-234. ill. https://doi.org/10.17167/mksz.2019.2.230-234

PATAKY Ildikó: A könyv hosszú útja. Ráday Gedeon 1783-as könyvbeszerzése = Lelkészek, nemesek, polgárok. Tanulmányok a Ráday Gyüjteményből / szerk. Berecz Ágnes. Bp.: Ráday Gyüjtemény, 2019. 48-69. ${ }^{3}$ A tanulmánykötet DOI azonosítója (a tanulmánynak külön nincs): https://doi.org/10.51183/RGYT_18

RÁCZKEVY Edit: 19. századi magánkönyvtárak orvosi vonatkozásai. Semmelweis Ignác magánkönyvtárának könyvei a Semmelweis Orvostörténeti Múzeumban = Orvostört. Közl. (65.) 2019. 1/4. 161-185.

Schier, Xystus Paul: Dissertatio de regiae Budensis bibliothecae Mathiae Corvini ortu, lapsu, interitu et reliquiis = Értekezés Corvin Mátyás budai királyi könyvtárának létrejöttéről, hanyatlásáról, pusztulásáról és maradványairól = Discussion of the establishment, decline, ruin, and the remains of Matthias Corvinus' royal library in Buda / az utószót írta, [...] szerk. [...] MonoK

3 A tanulmány téves impresszummal egyszer már megjelent a 2018-as publikációkat összegző könyvtörténeti bibliográfiában. 
István; [...] sajtó alá rend. [...] EkLER Péter; [...] ford. ÁвRAнÁм Zoltán. Bp.: Bibl. Nationalis Hungariae, 2019. 204 p. ill. (De Bibliotheca Corviniana,). (Supplementum Corvinianum; 5.)

A Bécsben, G. L. Schulz által 1766-ban kiadott eredeti mủ fotómásolatával.

Martin Rosnack 1776-ban írt életrajzi összefoglalójával és személyi bibliográfiájával

Monok István utószava: 187-190.

Az utószó angol nyelven: 191-194.

SCHMELCZER-PoHÁNKA Éva: Amikor az „inkvizítor” elbizonytalanodik. A tiltott műveket olvasó

Domsics Mátyás pécsi kanonok könyvgyüjteménye a 18. század derekán = Reformáció a Dél-Dunántúlon / szerk. Borsy Judit. Pécs: MNL Baranya M. Lvt.; Kaposvár: MNL Somogy M. Lvt.; Szekszárd: MNL Tolna M. Lvt., 2019. 423-444. ill.

SzABó Ádám: A Teleki család és a könyvek In: Teleki József...43-67. ill. https://doi.org/10.36820/ MTAKIK.KOZL.2019.TELEKI.2

TÜSKÉs Anna: Masonic Works in the Helikon Library of the Festetics Palace in Keszthely = Aufgeklärte Sozietäten, Literatur und Wissenschaft in Mitteleuropa / hrsg. von Dieter BREUER und Gábor Tüskés, in Zusammenarbeit mit Réka LengYel. Berlin- Boston: De Gruyter, 2019. 483-496. ill. https://doi.org/10.1515/9783110637649-030

TÜsKÉs Gábor: „,[D]er letzte Freimaurer in Ungarn aus der Zeit Kaiser Josef’s“.Zur Geschichte und Rekonstruktion der Kunst- und Büchersammlung = Aufgeklärte Sozietäten, Literatur und Wissenschaft in Mitteleuropa / hrsg. von Dieter BREUER und Gábor TÜSKÉs, in Zusammenarbeit mit Réka Lengyel. Berlin-Boston: De Gruyter, 2019. 497-542. ill. https://doi.org/10.1515/ 9783110637649-031

Viczay Viczay Mihály könyv- és mügyüjteményéről

VÁsÁRhelyi Judit, P.: Újabb könyvek Naprághy Demeter könyvtárából = Arrabona 57. 2019. 73-96. ill.

VERóK Attila: Küszöbönálló szemléletváltás az erdélyi szász könyvtártörténet-írásban? = Acta Universitatis de Carolo Eszterházy Nominatae. Sectio 46. 2019. 369-383.

\section{Olvasástörténet}

BALOGH Piroska: Aesthetica muliebris - avagy beszélhetünk-e „női esztétikáról” 18-19. századi magyar viszonylatban? $=$ Nőszerzők a 19. században... 15-30.

Dienes Dénes: Egy 16. századi református arisztokrata olvasási szokásai. Ecsedi Báthory István két könyve Sárospatakon $=$ Reformácia v strednej Európe... 1. köt. 443-449.

A Sárospataki Református Nagykönyvtár SS 259 és A.834 jelzetủ kötetéről

DóBÉK Ágnes: Olvasók, könyvek, könyvgyüjtők Györ városában $(1770-1820)$ = MKsz (135.) 2019. 2. 190-201. https://doi.org/10.17167/mksz.2019.2.190-201

KNAPP Éva: Palingenius Zodiacus vitae-je a magyarországi könyvtárakban $=$ Antikvitás \& reneszánsz (2.) 2019. 3. 93-110. https://doi.org/10.14232/antikren.2019.3.93-110

KNAPP Éva: Vergilius, Horatius és Ovidius magyarországi recepciója Palingenius Zodiacus vitae-jének magyar fordításaiban $=$ Antikvitás \& reneszánsz (2.) 2019. 4. 101-117. https://doi. org/10.14232/antikren.2019.4.101-117

MoNOK István: A 16. századi protestáns értelmiség olvasmányélményéről = Ige-idők. A reformáció 500 éve. Magyar Nemzeti Múzeum, 2017. április 26 - november 5. / szerk. Kiss Erika, ZászKALICZKY Márton, ZÁsZKALICZKY Zsuzsanna; térk. NAGY Béla. Bp.: MNM, 2019-.

Tanulmányok. 166-172. ill. 
MoNOK István: Über die Leseerfahrung der Gelehrten im ersten Jahrhundert der protestantischen Reform im Königreich Ungarn und in Siebenbürgen = Reformácia v strednej Európe... 2. köt. 696-707.

MonoK István-Zvara Edina: Die Bibliothek von Nicolaus Olahus = Nicolaus Olahus, 450. Tagungsband der internationalen Konferenz zum 450. Todestag von Nicolaus Olahus / Hrsg. von Emőke Rita SzILÁGYI. Wien : Inst. für Ungarische Geschichtsforschung in Wien; Bp.: Inst. für Literaturwissenschaft, Geisteswissenschaftliches Forschungszentrum der Ungarischen Akademie der Wissenschaften, 2019. 85-96.

SzAKÁL Anna: The emergence and composition of the reading society of the Unitarian College of Kolozsvár and its impact on the formation of the organised folklore collection in Transylvania = Kniha (Martin,Slovenská Národná Kniznica) 2019. 282-302.

SzAKÁL Anna: A Kolozsvári Unitárius Kollégium olvasókörének létrejötte, összetétele és hatása az erdélyi szervezett folklórgyűjtés megindulására = Kriza János Néprajzi Társaság évkve 2017. 25. 99-126.

Elhangzott előadás szerkesztett szövege: Néprajzi kutatástörténeti örökség Erdélyben. BBTE Magyar Néprajz és Antropológia Intézet - Kriza János Néprajzi Társaság - Kolozsvári Akadémiai Bizottság Néprajzi és Antropológiai Szakbizottsága - EME Bölcsészet-, Nyelv- és Történettudományi Szakbizottság, Kolozsvár, 2017. október 27.

Tо́тн Gergely: Állhatatosság és politika. Justus Lipsius munkásságának hatása (és hatástalansága) Révay Péter műveire = ItK (123.) 2019. 5. 567-584.

То́тн Szabolcs Barnabás: A nagyajtai olvasóegylet története = Acta siculica 2018/2019. 275-284. ill.

\section{A múlt neves könyvtárosai, bibliográfusai, újságírói}

ArAny Zsuzsanna: Előszó = Pardon... Az Új Nemzedék rovata Kosztolányi Dezső szerkesztésében, 1919-1921 / szerk. Arany Zsuzsanna Bp.: Osiris, 2019. 7-58.

Kosztolányi Dezső, mint az Új Nemzedék Pardon címü rovatának szerkesztője

BóDI Katalin: Elengedés. Kazinczy folyóiratcikkeinek sajtó alá rendezéséről = „Közöttünk a’ mester"... 97-104.

CzEnTHE Miklós: Mályusz Elemér és az Evangélikus Országos Levéltár megújítása = Credo (25.) 2019. 1/2. 18-30. ill.

DöвöR András: Helmeczy Mihály, a Jelenkor lapszerkesztője közéleti és szakmai hátterének vizsgálata a korabeli források tükrében = KEK (12.) 2019. 1. 199-219.

DöвӧR András: Underworld Dialogues of Sándor Szacsvay as Political Publicisms in Year 1789 of the Enlightenment-Era Newspaper Magyar Kurír = Media and literature... 193-205.

FeKETE Norbert: Női néven nőként bírálni. A beszédpozíció megszerzésének problémái Takáts Éva kritikusi fellépésekor $=$ Nőszerzők a 19. században... 31-46.

HÁrs Endre: „A dualizmus legrokonszenvesebb irodalmi megtestesülése osztrák-magyar hazánkban". Hevesi Lajos (1843-1910) és a századforduló publicisztikája = Filológiai közlöny (65.) 2019. 3. 131-139.

Hubert Gabriella, H.: Mályusz Elemér, az evangélikus könyvtáros = Credo (25.) 2019. 1/2. 31-34.

KÁRPÁTI Attila István: Wesselényi Miklós és az augsburgi Allgemeine Zeitung = Századok (153.) 2019. 3. 563-583.

KIss Jenő: Kesztyüs Tibor, 1933-2019= MNyelv (115.) 2019. 3. 369. https://doi.org/10.18349/ MagyarNyelv.2019.3.369

RózsA Mária: Karl Beck mint a Journal des Österreichischen Lloyd tárcarovatának szerkesztöje = ItK (123.) 2019. 4. 533-542. 
A magyar származású költő, Karl Beck (Beck Károly) újságírói és szerkesztői müködése az osztrák sajtóban

SCHMELCZER-PoHÁNKA Éva: Szepesy Ignác, az egyházmegyéket összekötő mecénás könyvtárszervező. Eger-Gyulafehér-Pécs = „A hazának hü őre és oszlopa”... 53-73. ill.

SzILÁGYI Zita Mária: Egy tudósítónő Brüsszelből. Báró Jósika Júlia hírtudósítói tevékenysége = Nőszerzők a 19. században... 185-204.

Tegzes Ferenc: „Magad uram, ha szolgád nincsen”. Szőnyi Ottó a Püspöki Könyvtár könyvtárosaként a Nagy Háború időszakában = „A hazának hủ őre és oszlopa”... 223-236.

TiboRI SzABó Zoltán: A náci lágereket megjárt Kornis Ottó újságíró sorsa= Me.dok (14.) 2019. 4. 65-90. ill.

Egy tehetséges, elfeledett újságíróról, irodalmi tevékenységéről és tragikus sorsáról

TöRöK Zsuzsa: A női írás kutatásának módszertana a digitális fordulat után. Wohl Stefánia esete a The Scotsmannel = Nőszerzők a 19. században... 205-220.

BORVÖLGYI GYÖRGYI 